\title{
DESEMPENHO VEGETATIVO E PRODUTIVO DE TRÊS CULTIVARES DE SOJA EM CINCO DENSIDADES POPULACIONAIS NAS ÉPOCAS NORMAL E SAFRINHA
}

LUIS FERNANDO SANGLADE MARCHIORI

Engenheiro Agrônomo

Orientador: Prof. Dr. Gil Miguel de Sousa Câmara

Dissertaçào apresentada à Escola Superior de Agricultura "Luiz de Queiroz", Unıversidade de Sào Paulo, para obtenção do título de Mestre em Agronomia, Área de Concentraçào: Fitotecnia.

PIRACICABA

Estado de São Paulo - Brasil

Janeiro - 1998 
Dados Internacionais de Catalogação na Publicação (CIP) DIVISÃo DE BIBLIOTECA E DOCUMENTAÇÃO - Campus "Luiz de Queiroz"/USP

Marchiori, Luis Fernando Sanglade

Desempenho vegetativo e produtivo de très cultivares de soja em cinco densidades populacionais nas épocas normal e safrinha / Luis Fernando Sanglade Marchiori. - . Piracicaba, 1998

55 p." : il.

Dissertação (mestrado) - Escola Superior de Agricultura Luiz de Queiroz, 1998. Bibliografia.

1. Densidade populacional 2. Época de safrinha 3. Edoca de semeadura 4. Produçắo vegetal 5. Soja 6. Variedade I. Título 


\section{DESEMPENHO VEGETATIVO E PRODUTIVO DE TRÊS CULTIVARES DE SOJA EM CINCO DENSIDADES POPULACIONAIS NAS ÉPOCAS NORMAL E SAFRINHA}

Aprovada em: 20/03/98

Comissão Julgadora:

Prof. Dr. Gil Miguel de Sousa Câmara ESALQ/USP

Prof. Dr. Natal Antonio Vello

Prof. Dr. Edgar Gomes Ferreira de Beauclair 


\section{DEDICO}

A meus pais José Maria e Neide

A minha esposa Célia e meu filho Lucas 


\section{AGRADECIMENTOS}

Ao Professor Gil Miguel de Sousa Câmara, pela oportunidade e amizade que me proporcionou.

A Professora Maria Cristina Stolf Nogueira, pela importante colaboração neste trabalho.

Aos Professores Júlio Marcos Filho e João Lúcio de Azevedo, pelo apoio e incentivo.

A diretoria da ESALQ, na pessoa do Professor Doutor Evaristo Marzabal Neves, pela oportunidade de realização do curso.

Ao Professor Doutor Marcos Bernardes, pela colaboração neste trabalho.

A bibliotecária Katia Maria de Andrade Ferraz, pela valiosa colaboração neste trabalho.

Aos colegas Clóvis Pereira Peixoto e Mônica Cagnin Martins, pela colaboração e sugestões espontâneas.

Aos colegas de curso, especialmente à Luiz Carlos Miranda e Itamar Gislon pelos momentos de amizade compartilhados.

Aos funcionários de campo do Departamento de Agricultura da ESALQ/USP pela colaboração nos trabalhos de campo.

Aos funcionários da Fazenda Areão - ESALQ/USP, José Luiz Mandro, Ricardo Vicente Michelotto, Marcos de Jesus Casadei, Armindo Amaro, Joaquim Francisco de Carvalho, João Alberto Bellato e particularmente a Valdinei Ribeiro Camargo, pela colaboração nos trabalhos de campo.

A senhorita Fernanda Barbosa, secretária da Incubadora de Empresas Agrozootécnicas pela colaboração durante o curso. 
A meus irmãos José Maria, Marcelo, Silvia, Mayra, cunhados Suzy e Carlos, sogra D. Hilda e especialmente a meu irmão Gilberto pelo apoio, incentivo e amizade.

A meus pais José Maria e Neide pelo exemplo de vida e empenho para a realização do curso.

A todos que, direta ou indiretamente, contribuíram para a realização do curso. 


\section{SUMÁRIO}

Página

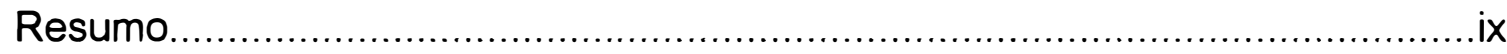

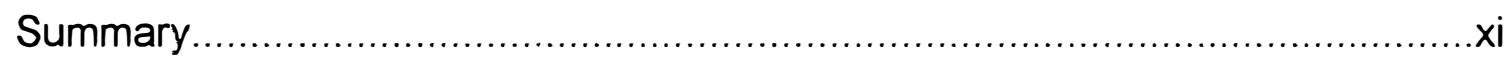

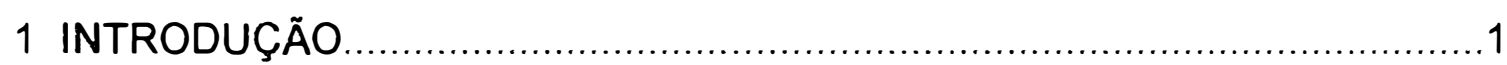

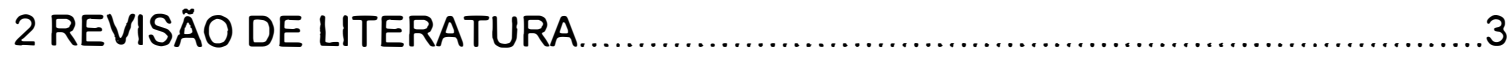

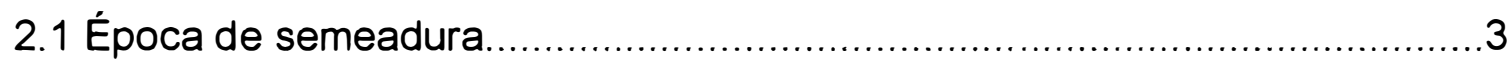

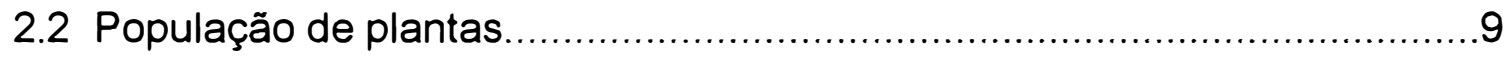

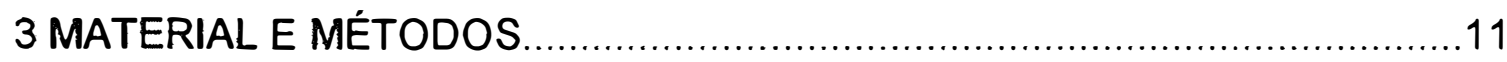

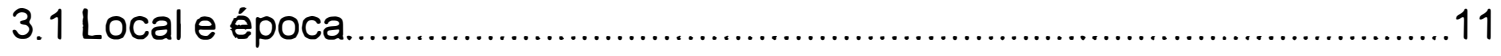

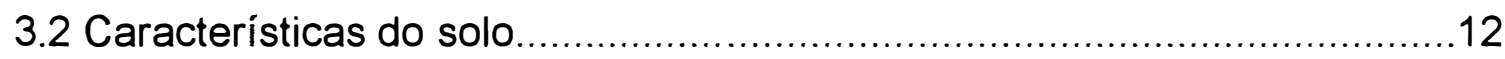

3.3 Preparo do solo, calagem e herbicidas utilizados................................12

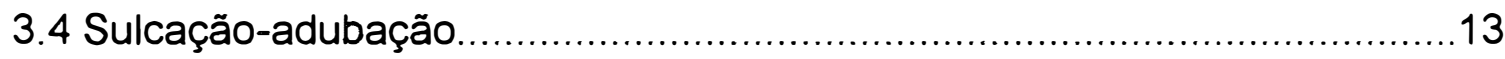

3.5 Tratamento e inoculação das sementes e semeadura............................13

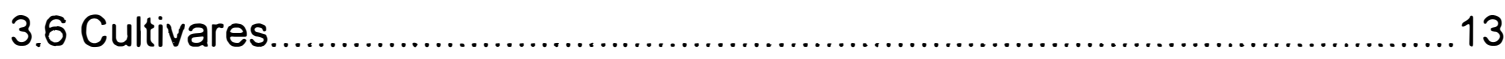

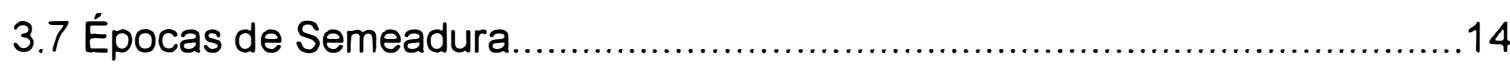

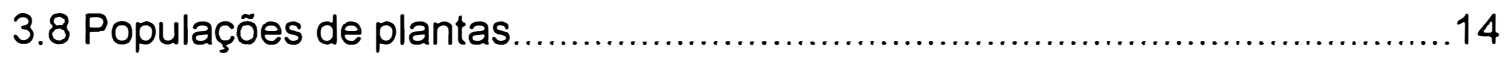

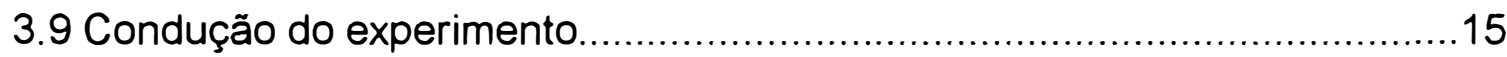

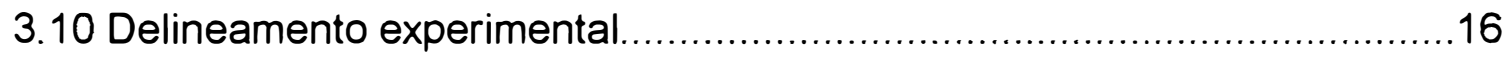

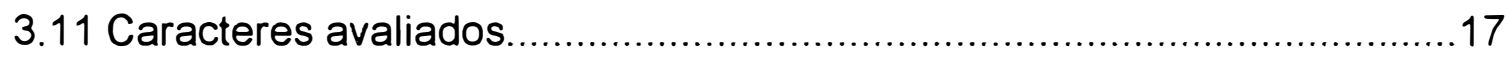

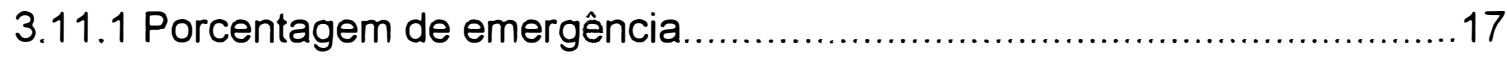

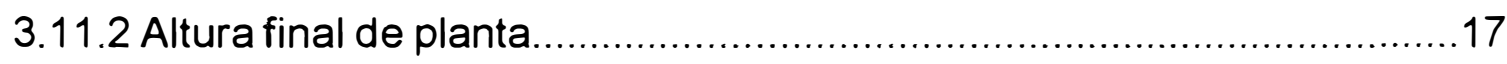

3.11.3 Altura de inserção da primeira vagem............................................18 
3.11.4 Diâmetro da haste principal....................................................... 18

3.11.5 Número final de nós vegetativos............................................. 18

3.11.6 Número de ramificações por planta..............................................18

3.11.7 Grau de acamamento....................................................... 18

3.11.8 Número total de vagens por planta.........................................19

3.11.9 Número de vagens no ápice por planta.......................................19

3.11.10 Número de vagens chochas por planta......................................19

3.11.11 Número diferenciado de sementes por vagem.............................19

3.11.12 Número de sementes por vagem..........................................19

3.11.13 Peso de sementes por planta.................................................... 19

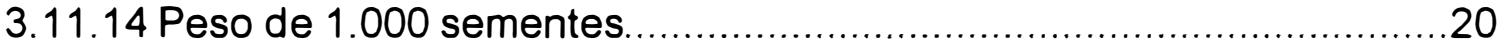

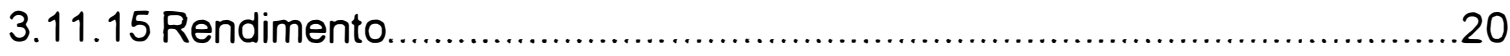

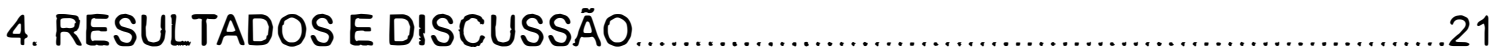

4.1 Porcentagem de emergência.................................................22

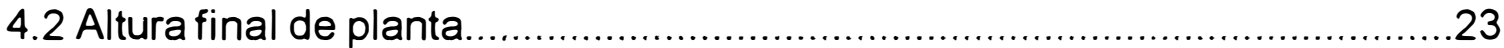

4.3 Altura de inserção da primeira vagem............................................ 25

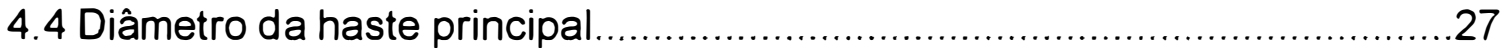

4.5 Número final de nós vegetativos..............................................29

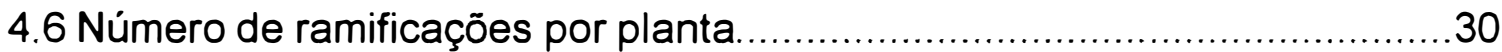

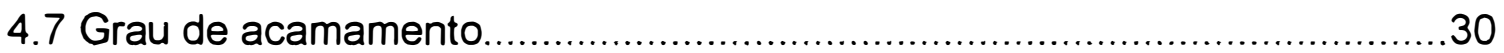

4.8 Número total de vagens por planta............................................. 32

4.9 Número de vagens no ápice por planta........................................34

4.10 Número de vagens chochas por planta.........................................34

4.11 Número diferenciado de sementes por vagem....................................35

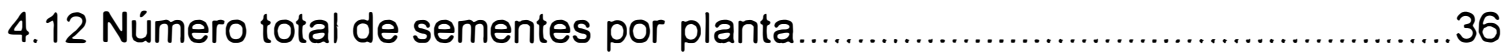

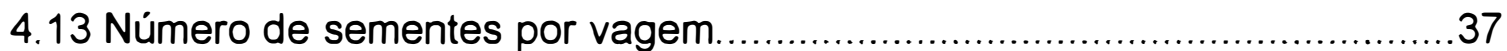

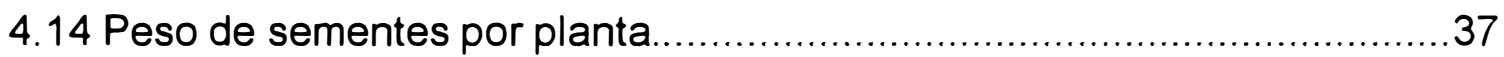

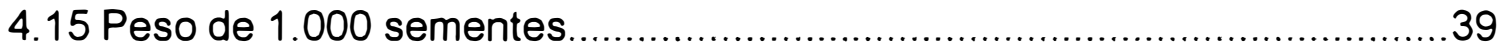




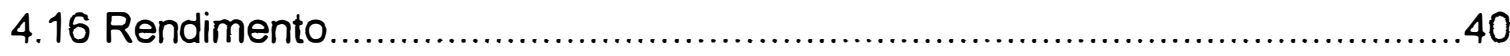

4.17 Considerações Gerais............................................................... 41

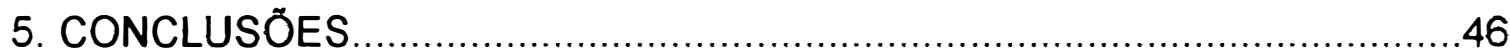

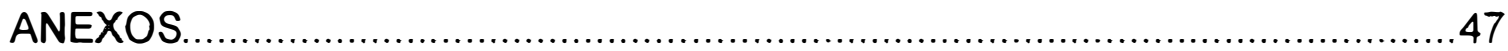

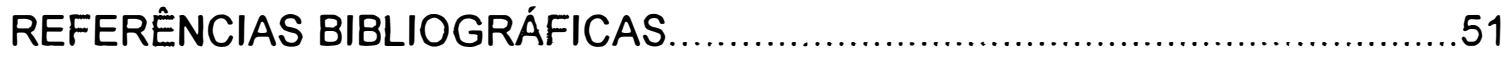




\title{
DESEMPENHO VEGETATIVO E PRODUTIVO DE TRÊS CULTIVARES DE SOJA EM CINCO DENSIDADES POPULACIONAIS NAS ÉPOCAS NORMAL E SAFRINHA
}

\author{
Autor: Luis Fernando Sanglade Marchiori \\ Orientador: Prof. Dr. Gil Miguel de Sousa Câmara
}

\section{RESUMO}

$\mathrm{Na}$ busca de alternativas técnicas que visem a obtenção de melhor produtividade e economicidade de um sistema de produção agrícola, agricultores da região Centro-Sul do Estado de São Paulo e da região Norte do Estado do Paraná, têm experimentado a semeadura de soja em época denominada "safrinha", que é realizada após a colheita da cultura de verão, semeada antecipadamente para dar espaço e tempo à cultura de safrinha. Entretanto, existem poucas informações técnicas e científicas quanto às principais características de manejo varietal e populacional, observando-se mera transferência da tecnologia de produção utilizada na época normal de semeadura para a época de safrinha. Visando colaborar para melhor compreensão do comportamento vegetativo e produtivo da cultura da soja em época de safrinha, realizou-se o presente trabalho de pesquisa que constou da avaliação comparativa de três cultivares de soja manejados sob cinco densidades populacionais, cultivados em épocas de semeadura normal e de safrinha. Para tanto, foram utilizados os cultivares de soja IAC-17, IAC-12 e 
IAC-19, respectivamente, com ciclos de maturação precoce, semi-precoce e médio, os quais foram conduzidos no espaçamento constante de $0,50 \mathrm{~m}$ entrelinhas e com 10,15, 20, 25 e 30 plantas por metro, de maneira a se obter a população equivalente a 200,300,400,500 e 600 mil plantas por hectare, respectivamente. Como época normal de semeadura adotou-se a data de 12/11/96 e como época de safrinha, 18/03/97. Cada época constituiu-se em um experimento independente, os quais foram analisados conjuntamente. Conduzidos em área experimental da ESALQ/USP, adotou-se o delineamento em blocos ao acaso com 15 tratamentos ( 3 cultivares $\times 5$ populações) por época, repetidos três vezes. Cada parcela foi composta por 5 linhas com 5 metros de comprimento, onde foram avaliados os seguintes parâmetros: emergência, altura final de planta, altura de inserção da primeira vagem, diâmetro da haste principal, número final de nós vegetativos, número de ramificações por planta, número de vagens por planta, número diferenciado de sementes por vagem, número total de sementes por planta, número de sementes por vagem, grau de acamamento, peso de sementes por planta, peso de 1000 sementes e rendimento. As principais conclusões são: a) o atraso na época de semeadura do periodo normal para a safrinha, reduz a altura de planta, o número de nós formados na haste principal, o número total de vagens e de sementes formadas por planta e o peso das sementes, refletindo-se em perdas de produtividade agrícola; b) independente da época de semeadura, quanto maior a densidade de plantas de soja na linha, maior a altura final das plantas, menor o diâmetro da haste principal, menor o número de ramificações por planta, menor o número total de vagens e de sementes formadas e menor 0 peso das sementes; c) em época normal de semeadura de soja, todos os

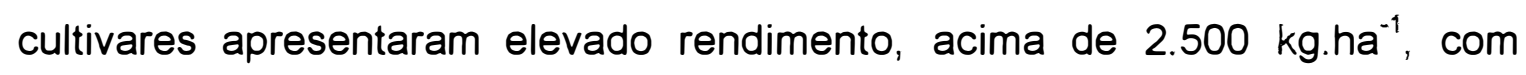
destaque para os cultivares IAC-12 e IAC-19 como os mais produtivos; d) em época de safrinha, o cultivar IAC-19 apresentou o melhor desempenho e maior rendimento de grãos. 


\section{PERFORMANCE OF THREE CULTIVARS OF SOYBEAN CULTIVATED IN FIVE PLANT POPULATIONS IN NORMAL AND "SAFRINHA" GROWING SEASON}

Author: Luis Fernando Sanglade Marchiori Adviser: Prof. Dr. Gil Miguel de Sousa Câmara

\section{SUMMARY}

In search of technical alternatives that aim at obtaining the best performance and economy of an agricultural production system, the farmers from the South region of São Paulo State and from the North region of Paraná State have experimented the soybean sowing in a period called "safrinha", that is done after the summer cultivation harvest, sown in advance in order to have time and space to the "safrinha" cultivation. However, there are few technical and scientific information related to the main characteristics of the cultivars and populacional management, observing the simple transference of the production technology used in the normal growing season to the "safrinha" growing season. Aiming to collaborating to a better comprehension of the vegetative and productive performance of the soybean cultivation in the "safrinha" growing season, the present research work was carried out to evaluate comparatively three soybean cultivars managed under five plant population, cultivated in the 
normal growing season and in the "safrinha" season. To do so, IAC-17, IAC-12 and IAC-19 soybean cultivars were used respectively, with early, semi-early and intermediate ripening cycles, which were conducted in a constant spacing of $0,50 \mathrm{~m}$ and with $10,15,20,25$ and 30 plants/m, obtaining plant population of 200,300,400, 500 and 600 thousand plants/ha, respectively. It was set the date 11/12/96 as the normal growing season and the date 03/18/97 as the "safrinha" season. Each season was an independent experiment, which was analyzed together. The experiment was carried on in experimental area of ESALQ/USP and the randomized blocks design with 15 treatments ( 3 cultivars $\times 5$ plant populations) each season was applied, replicating three times. Each plot had 5 lines of plant with $5 \mathrm{~m}$ long. The following parameters were estimated: emergence, final plant height, first pod insertion height, diameter of the main stem, number of pods in the apex, number of branches per plant, number of pods per plant, differentiate number of seeds per pod, total number of seeds per plant, number of seeds per pod, bending, weight of seeds per plant, weight of 1000 seeds and yield. The main conclusions are: a) the delay in the sowing time in the normal growing season compared to "safrinha" season reduces the height of the plant the number of the nodes formed in the main stem, the total number of pods and the seeds per plant, and the weight of seeds, leading to agricultural productivity losses; b) the higher soybean plant density in the line, the higher plant final height, the smaller main stem diameter, the smaller total number of pods and seeds formed and the smaller weight of seeds, not depending on the sowing season; $c$ ) in the soybean normal sowing season, all the cultivars presented high yield, more than 2500 $\mathrm{kg} \cdot \mathrm{ha}^{-1}$, highlighting IAC-12 and IAC-19 cultivars as the most productive ones; d) in "safrinha" sowing season, the intermediate cycle soybean cultivars, as the IAC-19, present the best grain yield performance. 


\section{INTRODUÇÃO}

Certos fatores ambientais tem efeitos importantes sobre a produtividade da cultura da soja, tais como umidade, temperatura e fotoperíodo, que estão intimamente relacionados com as diferentes épocas do ano, principalmente em regiões de maior latitude, onde essas diferenças são mais acentuadas.

A faixa adequada de temperatura para o desenvolvimento da soja situa-se entre os $20^{\circ} \mathrm{C}$ e $30^{\circ} \mathrm{C}$, sendo melhores, as mais próximas dos $30^{\circ} \mathrm{C}$. Além desta exigência térmica, a soja é uma das espécies mais sensíveis ao fotoperíodo, sendo considerada planta de dia curto. Em função disto e da dependência hídrica, desvios na época de semeadura podem acarretar num encurtamento do ciclo da cultura resultando em plantas menores e menos produtivas.

Nos últimos anos, os produtores, principalmente aqueles da região Norte do Paraná até a região Centro-Sul de São Paulo, devido ao bom preço do produto, tem experimentado a semeadura da soja em uma época alternativa chamada "safrinha", que é realizada após a colheita do milho semeado antecipadamente, ou mesmo em sucessão à própria cultura da soja.

Esta alternativa de produção é conduzida utilizando-se a mesma população de plantas recomendada para a época de semeadura normal, porém, em função dessa época não contemplar as exigências bioclimáticas ideais, resulta em plantas pouco desenvolvidas e com menor rendimento.

Novos cultivares, principalmente resistentes ao cancro da haste, são cada vez mais requisitados pelos produtores, pressionando os programas 
nacionais de melhoramento genético de soja a serem mais ágeis na recombinação genética e na seleção de linhagens promissoras.

Em resposta à demanda do setor produtivo, as instituições com programas de melhoramento genético de soja têm sido eficientes, lançando anualmente novos cultivares de soja, resistentes a essa importante doença da cultura, porém, demonstrando comportamento vegetativo e produtivo diferenciado entre produtores, que nem sempre semeiam na mesma época, assim como, nem sempre usam a mesma população de plantas. Tais situações indicam a necessidade atual de se estudar novos cultivares em diferentes épocas de semeadura e em diferentes niveis populacionais.

Sustentado na hipótese de que para cada cultivar de soja existe uma indicação de época ideal para semeadura, assim como existem dentre os cultivares aqueles que se sobressaem em condições de semeadura em épocas diferentes da recomendada, objetivou-se avaliar e comparar com a época de semeadura normal, o desempenho vegetativo e produtivo de três cultivares de soja, recomendados para o estado de São Paulo, manejados sob cinco populações de plantas, na época de semeadura considerada "safrinha". 


\section{REVISÃO DE LITERATURA}

A diversidade climática de cada região, aliada ao lançamento anual de um grande número de cultivares com sensibilidade diferencial aos fatores de clima, têm impossibilitado o estabelecimento de uma época ideal para todos os cultivares e regiōes (Urben Filho \& Souza, 1993).

Assim, a época de semeadura mais propícia para uma cultura depende, simultaneamente, da região e do cultivar. O que justifica os estudos visando estabelecer épocas para esses diversos cultivares nas mais variadas regiões, é a contribuição para minimizar as perdas de produção causadas por semeaduras em épocas não propícias. Além da época, outros fatores afetam a produtividade de grãos e demais características agronômicas da soja, merecendo destaque a população de plantas. Dessa maneira, estudos de populações de plantas, visando estabelecer as mais adequadas, também fazem-se necessários.

Em termos práticos, os trabalhos desenvolvidos com populações de plantas visam estabelecer o arranjo ou a distribuição de plantas na área de produção que venha a resultar em maior rendimento de grãos (Urben Filho \& Souza, 1993).

\section{1 Época de semeadura}

Quando o produtor de soja opta por uma determinada época de semeadura, ele está escolhendo uma certa combinação entre a fenologia da 
cultura e a distribuição dos atributos do clima do ambiente de produção, que poderá culminar com o elevado ou reduzido rendimento. Dentre os principais atributos do clima que interferem com o desenvolvimento e rendimento da soja, têm-se a umidade, a temperatura e o fotoperíodo (Câmara, 1992).

Segundo Vernetti (1983), o zoneamento climático da cultura da soja tem a finalidade de indicar as regiões onde as condições de clima são mais favoráveis. Estas regiões são classificadas em aptas, marginais e inaptas. Entretanto, sabe-se que, mesmo nas melhores regiões do mundo, o zoneamento climático não elimina problemas como a ocorrência de secas, uma vez que as suas condições climáticas estão sujeitas a fenômenos meteorológicos adversos. A freqüência e a intensidade desses fenômenos é menor nas regiões preferenciais e maior nas marginais, podendo chegar a niveis intoleráveis nas regiões inaptas.

O desenvolvimento da soja está condicionado pelos fatores ambientais, sendo que a água é o principal fator que altera sua produtividade no tempo e no espaço. $O$ consumo de água pela planta varia com as condições climáticas, práticas de manejo e ciclo de maturação da cultivar. A resposta desta cultura ao fotoperíodo e à temperatura, define sua zona agroclimática de adaptação (FAO, 1995).

A soja é bastante resistente à seca devido a seu extenso sistema radicular e ao seu relativamente longo período de floração, que permite a soja escape a curtos períodos de seca. A falha em fixar as vagens, devido à seca, pode ser compensada por sua ótima fixação em conseqüência do aparecimento de flores mais tardias durante um período de boas condições de umidade no solo. O período mais crítico em relação à água é durante o crescimento dos grãos. É nesse período que a irrigação é mais benéfica (Vernetti, 1983).

De acordo com Marcos Filho (1986), as regiões aptas à cultura da soja são as que apresentam boa distribuição de precipitações pluviais (500$700 \mathrm{~mm}$ ) durante o ciclo das plantas. 
A temperatura exerce influência sobre todas as fases fenológicas da planta, sendo este um fator que deve ser considerado na escolha da época de semeadura da soja, quando se visa obter rendimentos elevados. Temperaturas entre 25 e $30^{\circ} \mathrm{C}$ favorecem tanto a emergência das plântulas como a formação de nódulos e o desenvolvimento das plantas de soja, sendo a última considerada ótima; temperaturas acima de $30^{\circ} \mathrm{C}$ exercem efeitos depressivos sobre a intensidade de desenvolvimento das plantas (Marcos Filho, 1986).

Bergamaschi et al. (1977) afirmaram que semeaduras mais tardias realizadas em regiões mais quentes permitem que a planta de soja atinja porte razoável, com menor redução no seu potencial de produção. Assim, visando o rendimento da cultura, os cultivares de ciclo longo são mais vantajosos para semeaduras tardias em locais quentes pois, nessas condições, os precoces, mesmo contando com boa disponibilidade térmica, tem seu porte e altura da inserção das primeiras vagens consideravelmente reduzidos, aumentando as perdas na colheita mecanizada.

Segundo Medina (1994), cultivares precoces de soja semeados no estado de São Paulo durante os meses de outubro e novembro, desenvolvem seus processos de maturação e colheita sob condições climáticas desfavoráveis, caracterizadas por elevadas temperaturas e umidades relativas do ar.

A soja é sensivel à duração do dia, ou melhor, à duração do período de escuro (nictoperíodo), para a indução da formação de botões florais (Câmara, 1992). É classificada como planta fotoperiódica de dias curtos, florescendo quando o comprimento dos dias é inferior a determinado valor, denominado fotoperíodo crítico (FC). Assim, a soja é induzida a florescer, quando o valor do fotoperíodo do ambiente de cultivo é inferior ao fotoperíodo crítico, ou seja, quando as noites são mais longas que a diferença (24-FC) horas. 
O principal fator de adaptação de um cultivar de soja a determinada região é a sua resposta ao comprimento do dia. Biologicamente pode-se definir fotoperiodismo como sendo as mudanças de comportamento, que os animais e as plantas apresentam perante as modificações diárias do fotoperiodo (Câmara, 1991).

O fotoperiodo é um dos fatores mais importantes a serem considerados na recomendação de cultivares e de época de semeadura dentro de uma determinada região. A soja é sensivel ao comprimento da noite, para a indução da formação dos botões florais (Marcos Filho, 1986; Câmara, 1992).

O efeito mais conhecido do fotoperíodo na soja é a redução do período compreendido entre a emergência das plântulas e a floração, portanto, do ciclo de maturação. À medida que uma variedade é levada para latitudes menores ou quando sua semeadura é atrasada, obtém-se plantas mais baixas e menos produtivas (Sediyama et al., 1972; Marcos Filho, 1986; Câmara, 1991).

O manejo da cultura em relação à época de semeadura, à população de plantas e ao cultivar, são fatores importantes que afetam a produção (Câmara, 1992). Estes fatores têm merecido a atenção de pesquisadores no sentido de indicar as melhores soluções através do melhoramento genético, nutrição mineral, controle de pragas, além de outras práticas culturais, visando a elevação da produtividade, da qualidade do produto e a estabilidade da produção (Marcos Filho \& Novembre, 1990).

Pesquisas realizadas no Brasil, demonstram que a época de semeadura é a variável que produz maior impacto sobre a produção da cultura da soja (Rocha et al., 1984). Para as condições brasileiras, a época de semeadura varia em função do cultivar, região de cultivo e condições ambientais do ano agrícola, geralmente apresentando uma faixa recomendável de outubro a dezembro (Nakagawa et al., 1983). Observaram, ainda, que o mês 
de novembro, de maneira geral, tem proporcionado os melhores resultados de produtividade nos estados em que a cultura é cultivada tradicionalmente.

Estudando o comportamento da soja na região de Botucatu-SP, Nakagawa et al. (1983), atribuíram a redução na produção de sementes de soja, ao atraso nas datas de semeadura, à medida em que estas eram atrasadas de meados de outubro ao início de janeiro, principalmente devido aos efeitos de redução do fotoperíodo associada à ocorrência de baixas temperaturas e à falta de umidade no solo no final do ciclo da cultura.

A época de semeadura, além de afetar o rendimento, afeta também e de modo acentuado, a arquitetura e o comportamento da planta. Semeadura em época inadequada pode causar redução drástica no rendimento, bem como, dificultar a colheita mecanizada, de tal modo que as perdas na colheita podem chegar a niveis muito elevados (EMBRAPA, 1996a).

A altura de planta é uma característica influenciada pelo genótipo, de maneira que os cultivares de ciclo longo e de hábito de crescimento indeterminado geralmente são mais altos (Marcos Filho, 1986). Entretanto, esse autor constatou que a época de semeadura, a população de plantas, as condições ambientais (temperatura, umidade e luminosidade) e as propriedades físicas e químicas do solo também exercem influência sobre a altura da planta.

Vários autores verificaram redução na altura das plantas de soja, devido à menor duração do período vegetativo, relacionada a atrasos na semeadura (Sediyama et al., 1972; Tragnago \& Bonetti, 1984; Marcos Filho, 1986; Bhering, 1989; Câmara, 1991).

Sanches \& Yuyama (1979) estudando o comportamento de dois cultivares de soja em oito épocas de semeadura verificaram que o atraso no plantio causou diminuição no ciclo da planta (vegetativo ou reprodutivo), sendo isto, uma conseqüência do fotoperiodo. Com a redução do ciclo da planta houve diminuição na altura da planta, número de vagens por planta, número de 
grãos por vagem e, consequentemente, redução na produção. Por outro lado, a altura da inserção da primeira vagem aumentou.

Ainda considerando componentes de produção relacionados ao rendimento de sementes, constata-se que a redução na produção devido ao atraso na época de semeadura está mais associada ao menor número de sementes produzidas do que ao decréscimo no tamanho e, consequentemente, ao peso de sementes (Nakagawa et al., 1983).

A época normal de semeadura para a cultura de soja, no estado de São Paulo, tem seu período preferencial entre a segunda quinzena de outubro e a primeira do mês de novembro. Fora desse intervalo, poderá ocorrer redução na altura das plantas e no rendimento, o que pode comprometer a economicidade da lavoura (Miranda \& Mascarenhas, 1986).

Segundo Nakagawa et al. (1983), nas condições do estado de São Paulo, o maior desenvolvimento das plantas e as maiores produções têm sido conseguidas em semeadura no mês de novembro. Entretanto, as semeaduras mais tardias, apesar de oferecer melhores resultados quanto à qualidade de sementes, ocasionam menor crescimento das plantas e uma diminuição na duração dos estádios de desenvolvimento, com reflexos no rendimento. Para contornar esta situação, uma das formas empregadas, é modificar a população de plantas, diminuindo os espaçamentos entre linhas, e aumentando o número de plantas na linha (Rosolem et al., 1983).

A época denominada "safrinha" é uma opção normalmente realizada em sucessão à cultura da soja, em época normal, ou à outra cultura, que foi semeada no início do período das chuvas. No estado de São Paulo, a safrinha é instalada em fevereiro ou março de cada ano, após a colheita da cultura de verão.

Essa prática ainda pouco disseminada no Brasil, iniciou-se em regiōes produtoras de milho localizadas no estado do Paraná e ao sul do 
Estado de São Paulo, onde após a colheita da gramínea, é semeada a cultura da soja, visando renda adicional para os agricultores (EMBRAPA, 1997).

Não existem muitas informações sobre cultivares mais indicados para essas condições, uma vez que a seleção de cultivares em semeadura tardia é muito prejudicada por ataque de percevejos. No entanto, a lógica e a experiência permitem indicar que cultivares de ciclo de maturação médio e semi-tardios têm maiores potenciais de rendimento (EMBRAPA, 1995).

\subsection{População de plantas}

A distribuição das plantas no campo é feita pela variação do espaçamento e da densidade na linha. De acordo com Costa Val et al. (1971), os espaçamentos mais recomendados são os de 60 e $70 \mathrm{~cm}$ e as densidades de 20 a 30 plantas por metro linear.

Vários estudos têm demonstrado que a melhor população de plantas para o sistema convencional de plantio é de aproximadamente 400.000 plantas. ha ${ }^{-1}$, havendo tolerância da cultura para variações na ordem de $20 \%$ a $25 \%$ desse número para mais ou para menos. Entretanto, a melhor população depende da região, época de semeadura e cultivar (Costa Val et al., 1971; EMBRAPA, 1996a).

Segundo Gaudêncio et al. (1990), a população é fator determinante para o arranjo das plantas de soja, uma vez que, esta influencia o crescimento. $O$ excesso de plantas, mesmo nos casos em que não se observa redução no rendimento, modifica a arquitetura e o aproveitamento de luz, deixando-as mais sujeitas ao acamamento, podendo ocasionar perdas na colheita.

Os mesmos autores, procurando definir a melhor população de plantas de soja na Região Centro-Sul do Paraná, instalada em semeadura 
direta, observaram que a população de 280.000 plantas. ha $^{-1}$ não reduziu 0 rendimento da soja, em comparação com a população de até 650.000 plantas. ha $^{-1}$, para os cultivares estudados, o que permite concluir que nas áreas onde o acamamento da soja é freqüente, populações de 280.000 a 350.000 plantas. ha ${ }^{-1}$ podem ser utilizadas.

O espaçamento recomendado para a cultura da soja varia de 0,40m a 0,70m entre as linhas, sendo que atualmente, há predominância de valores mais reduzidos, entre 0,40 e 0,50m (EMBRAPA, 1995).

Bueno et al. (1975) estudando o comportamento de dois cultivares tardios de soja em três épocas de semeadura, dois espaçamentos e três densidades de plantio, observaram que o espaçamento de $60 \mathrm{~cm}$ e densidade de 10 plantas. $\mathrm{m}^{-1}$ (aproximadamente 165.000 plantas.ha ${ }^{-1}$ ) apresentaram melhores resultados, sem prejuizos à produção e com menor gasto de sementes. 


\section{MATERIAL E MÉTODOS}

\subsection{Local e época}

A pesquisa foi realizada em área experimental da Escola Superior de Agricultura "Luiz de Queiroz", no município de Piracicaba-SP, localizada a $22^{\circ} 41^{\prime}$ de latitude Sul, $47^{\circ} 38^{\prime}$ de longitude Oeste e $573 \mathrm{~m}$ de altitude.

O período foi o ano agrícola 1996/97, sendo 12 de novembro de 1996 realizada a semeadura da época normal de soja e 18 de março de 1997 , a semeadura da época "safrinha", ou seja, após o ciclo vegetativo da época considerada normal.

Os dados climáticos foram coletados na estação meteorológica automática localizada na Fazenda Areão - ESALQ/USP, onde se conduziu o experimento e são apresentados na tabela 1.

Tabela 1. Médias diárias de temperatura e precipitação. Piracicaba, SP

\begin{tabular}{ccc}
\hline \hline Meses / Ano & Temperatura média $\left({ }^{\circ} \mathrm{C}\right)$ & Precipitação Total $(\mathrm{mm})$ \\
\hline Nov/96 & 22,9 & 198,7 \\
Dez/96 & 24,1 & 187,9 \\
Jan/97 & 23,7 & 343,7 \\
Fev/97 & 24,4 & 84,7 \\
Mar/97 & 23,7 & 73,1 \\
Abr/97 & 21,8 & 42,0 \\
Mai/97 & 18,8 & 51,6 \\
Jun/97 & 17,1 & 107,7 \\
Jul/97 & 18,1 & 19,3 \\
\hline \hline
\end{tabular}

Fonte: Estação meteorológica automática - Fazenda Areão (ESALQ/USP). 


\subsection{Características do solo}

O local apresenta solo Podzólico Vermelho Escuro, profundo, com boa drenagem e textura muito argilosa, contendo $62,0 \%$ de argila total, $11,0 \%$ de silte e $27,0 \%$ de areia. Foram coletadas amostras compostas desse solo, as quais foram enviadas ao Laboratório de Análises Químicas de Solos do Departamento de Ciência do Solo da ESALQ/USP para procedimento da análise química, conforme observado na tabela 2 .

\subsection{Preparo do solo, calagem e herbicidas utilizados}

A análise do solo correspondente às duas áreas foi realizada previamente (tabela 2) e o solo preparado através de uma aração com arado de aivecas na profundidade de $35 \mathrm{~cm}$, incorporando a primeira dose de calcário ( $1 / 2$ da dose), seguida de uma gradeação, quando foi incorporada a segunda $1 / 2$ da dose de calcário, realizando-se o primeiro nivelamento do terreno. $O$ segundo nivelamento foi efetuado junto com a incorporação dos herbicidas trifluralina e imazaquim nas doses de 2,0 L.ha ${ }^{-1}$ e 1,0 L. ha ${ }^{-1}$, respectivamente. As plantas daninhas não controladas pelos herbicidas, foram eliminadas por meio de capina com enxadas.

Tabela 2. Composição química do solo da área experimental. Piracicaba, 1996

\begin{tabular}{cccccccccccc}
\hline \hline Prof. & $\mathrm{PH}$ & $\mathrm{M} . \mathrm{O}$ & $\mathrm{P}$ & $\mathrm{K}$ & $\mathrm{Ca}$ & $\mathrm{Mg}$ & $\mathrm{Al}$ & $\mathrm{H}+\mathrm{Al}$ & $\mathrm{SB}$ & $\mathrm{T}$ & $\mathrm{V}$ \\
\cline { 5 - 8 }$(\mathrm{cm})$ & $\left(\mathrm{CaCl}_{2}\right)$ & $\left(\mathrm{g} \cdot \mathrm{dm}^{-3}\right)$ & $\left(\mathrm{mg} \cdot \mathrm{dm}^{-3}\right)$ & & & $\left(\mathrm{cmol}_{\mathrm{c}} \mathrm{dm}^{-3}\right)$ & & & $(\%)$ \\
\hline $00-20$ & 4,4 & 24,0 & 4,0 & 0,26 & 3,2 & 1,4 & 0,3 & 7,2 & 4,9 & 12,1 & 40,0 \\
$20-40$ & 4,2 & 20,0 & 4,0 & 0,15 & 2,0 & 0,8 & 0,8 & 7,2 & 3,0 & 10,2 & 29,0 \\
\hline
\end{tabular}




\subsection{Sulcação-adubação}

Após o preparo do solo, providenciou-se a sulcação-adubação da área experimental, por meio de sulcador-adubador, com hastes espaçadas a $0,50 \mathrm{~m}$ e regulagem de saída de fertilizante para distribuir o equivalente a 400 $\mathrm{kg} \cdot \mathrm{ha}^{-1}$ da fórmula 00-20-15, correspondendo à recomendação de $80 \mathrm{~kg} \mathrm{ha}^{-1}$ de $\mathrm{P}_{2} \mathrm{O}_{5}$ e $60 \mathrm{~kg} \cdot \mathrm{ha}^{-1}$ de $\mathrm{K}_{2} \mathrm{O}$. Previamente à semeadura, providenciou-se a inoculação das sementes dos cultivares de soja com inoculante contendo Bradyrhizobium japonicum, visando-se promover a fixação do nitrogênio do ar em uma forma assimilável pelas raízes.

\subsection{Tratamento e inoculação das sementes e semeadura}

Visando-se a proteção das sementes contra a ação do complexo de fungos do solo, efetuou-se o tratamento das mesmas, com o uso de fungicida (Carboxin-Thiran), na dose equivalente a $280 \mathrm{ml} .100 \mathrm{~kg}^{-1}$ de sementes, inoculando-as em seguida com inoculante turfoso aplicado na dose de $0,6 \mathrm{Kg} .40 \mathrm{Kg}^{-1}$ de sementes.

A semeadura foi realizada manualmente de forma a obter-se uniformidade na distribuição das sementes no solo. Optou-se por semear o dobro do número de sementes necessário, objetivando-se obter populações iniciais de plantas acima dos valores desejados conforme tabela 3 , promovendo-se o desbaste do excesso de plântulas.

\subsection{Cultivares}

Foram utilizados os cultivares mais novos recomendados para o estado de São Paulo, associados a sua representatividade quanto à área 
cultivada e resistentes ao cancro da haste, a saber: IAC-17 (ciclo precoce), IAC-12 (ciclo semi-precoce) e IAC-19 (ciclo médio).

\section{7 Épocas de Semeadura}

Foram estudadas duas épocas de semeadura com intervalo de 125 dias.

A semeadura realizada em 12 de novembro de 1996, representou a época normal (E1) para a semeadura de soja no estado de São Paulo.

A data de 18 de março de 1997, representou a condição de semeadura em "safrinha" para soja (E2), quando mesmo ocorrendo temperaturas e umidades favoráveis, não há relação fotoperiódica favorável à soja.

\subsection{Populações de plantas}

Foi adotado o espaçamento fixo de 0,50 m entre linhas de soja, de maneira que a variação populacional estudada, foi obtida pela variação no número de plantas por metro de linha, como se observa na tabela 3.

Uma vez estabilizada a emergência de plantas nas parcelas experimentais, entre 10 e 15 dias após a semeadura, o excesso de plantas foi retirado manualmente para que fossem obtidas as populações propostas. 
Tabela 3. População de plantas em cinco densidades de semeadura, mantendo-se espaçamento constante.

\begin{tabular}{cccc}
\hline $\begin{array}{c}\text { Espaçamento } \\
(\mathrm{m})\end{array}$ & $\begin{array}{c}\text { Metros de } \\
\text { linha.ha }^{-1}\end{array}$ & $\begin{array}{c}\text { Densidade } \\
\left(\text { plantas. }^{-1}\right)\end{array}$ & $\begin{array}{c}\text { População } \\
\left.\text { plantas.ha }^{-1}\right)\end{array}$ \\
\hline 0,50 & 20.000 & 10 & 200.000 \\
0,50 & 20.000 & 15 & 300.000 \\
0,50 & 20.000 & 20 & 400.000 \\
0,50 & 20.000 & 25 & 500.000 \\
0,50 & 20.000 & 30 & 600.000 \\
\hline \hline
\end{tabular}

\subsection{Condução do experimento}

O ciclo da cultura foi acompanhado com base na "Escala Fenológica" proposta por Fehr \& Caviness (1977), sendo que após a emergência das plantas, adotaram-se os tratos culturais necessários.

Para acompanhamento da população de pragas foi utilizada a técnica do pano-de-batida. Não houve ocorrência de lagartas. Para o controle do complexo de percevejos, adotou-se a pulverização do inseticida endosulfan, na dosagem de 0,65 L.ha ${ }^{-1}+0,5 \%$ de $\mathrm{NaCl}$, apenas quando o levantamento populacional dessa praga apresentava dois percevejos por pano-de-batida, 0 mesmo critério de nível de dano econômico usado em lavouras para sementes EMBRAPA (1996a).

A irrigação das parcelas, principalmente na época "safrinha", quando necessária, foi realizada para permitir a emergência das plântulas e garantir o pleno desenvolvimento vegetativo e reprodutivo da cultura. 


\subsection{Delineamento experimental}

Foram conduzidos dois experimentos individuais em áreas próximas, instalados em cada época de semeadura, segundo o esquema fatorial, com três niveis de cultivares e cinco niveis de populações (densidades), distribuidos em três blocos, segundo o modelo matemático, a seguir:

$Y_{i j k l}=\mu+a_{i}+b_{j(i)}+c_{k}+d_{1}+(a c)_{i k}+(a d)_{i l}+(c d)_{k l}+(a c d)_{i k l}+e_{i j k l}$ com $\mathbf{i}=1,2 ; \mathbf{j}=1, \ldots, 5 ; \mathbf{k}=1,2,3$ e $\mathbf{l}=1, \ldots, 5$, sendo:

$\mu=$ constante inerente ao modelo;

$a_{i}=$ efeito da i-ésima época;

$\mathbf{b}_{\mathbf{j}(\mathrm{i})}=$ efeito do j-ésimo bloco, dado i-ésima época;

$\mathbf{C}_{\mathrm{k}}=$ efeito do $\mathrm{k}$-ésimo cultivar;

$\mathbf{d}_{\mathbf{l}}=$ efeito da l-ésima densidade;

$(\mathrm{a} c)_{i k}=$ efeito da interação de época com cultivar;

$(\mathrm{ad})_{i 1}=$ efeito da interação de época com densidade;

$(c d)_{k l}=$ efeito da interação de cultivar com densidade;

$(\operatorname{acd})_{i k l}=$ efeito da interação de época com cultivar e densidade;

$\mathbf{e}_{i j k l}=$ erro experimental, não observável, tal que $\mathbf{e}_{i j k l} \cap N\left(0, \sigma^{2}\right) e$ independentes, em conseqüência $Y_{i j k ı} \cap N\left(\mu_{i k l}, \sigma^{2}\right)$ e independentes.

As parcelas foram constituidas por cinco linhas de $5,0 \mathrm{~m}$ de comprimento, sendo as duas linhas externas consideradas como bordaduras. Como área útil foram utilizadas as três linhas centrais, sendo eliminadas, a título de bordadura, 0,50m de cada extremidade.

$\mathrm{Na}$ análise estatistica foram considerados os dois experimentos individualmente com o intuito de verificar a homogeneidade de variâncias entre 
eles. Verificando-se que as exigências do modelo matemático proposto foram aproximadamente satisfeitas, assim procedeu-se a análise conjunta envolvendo as duas épocas de semeadura.

Para os efeitos estatisticamente significativos, pelo teste $F$ na análise de variância, foi aplicado o teste $t$ (DMS), com o objetivo de testar a diferença entre médias duas a duas.

As análises estatísticas foram realizadas através do aplicativo SAS.

\subsection{Caracteres avaliados}

\subsubsection{Porcentagem de emergência}

Foi determinada aos 14 dias após a emergência, por meio da contagem do número de plantas emergidas nas três linhas centrais de cada parcela.

Os demais caracteres, a seguir relatados, foram avaliados por ocasião da maturação em campo (estádio $R_{8}$ ) e na pré-colheita das parcelas, com base em amostras constituídas de 10 plantas ao acaso por parcela;

\subsubsection{Altura final de planta}

Considerou-se como altura final de planta, a distância compreendida entre a superfície do solo e o ápice da haste principal da planta. 


\subsubsection{Altura de inserção da primeira vagem}

Relativa à distância compreendida entre a superfície do solo e o ponto de inserção da primeira vagem na haste principal da planta.

\subsubsection{Diâmetro da haste principal}

Foi obtido através do uso de um paquímetro, sendo feita a leitura em $\mathrm{mm}$ e posteriormente padronizada para $\mathrm{cm}$, medindo-se a região compreendida entre o colo da planta e a cicatriz do nó cotiledonar.

\subsubsection{Número final de nós vegetativos}

Utilizando as amostras constituídas de 10 plantas, realizou-se a contagem do número de nós no estádio $R_{8}$.

\subsubsection{Número de ramificações por planta}

Obtido por contagem direta do número de ramos inseridos na haste principal da planta e nas ramificações primárias desta.

\subsubsection{Grau de acamamento}

Foi determinado por notas atribuídas em escala variável de 1 a 5 , onde 1 e 5 representaram respectivamente, o maior e o menor grau de resistência ao acamamento. 
3.11.8 Número total de vagens por planta

Através da contagem direta do total das vagens existentes.

3.11.9 Número de vagens no ápice por planta

Através da contagem direta das vagens existentes no ápice.

3.11.10 Número de vagens chochas por planta

Através da contagem direta das vagens chochas, ou sem a formação de sementes, existentes.

\subsubsection{Número diferenciado de sementes por vagem}

Por meio da contagem direta, foram determinados os números de vagens com 1, 2 e 3 sementes. Pelo mesmo método, determinou-se o número total de sementes por planta.

\subsubsection{Número de sementes por vagem}

Obtido pela relação entre o número total de sementes existentes e o número total de vagens.

\subsubsection{Peso de sementes por planta}

Obtido pelo peso médio do total de sementes das plantas amostradas. 
3.11.14 Peso de 1.000 sementes

Foram efetuados procedimentos segundo prescrições estabelecidas pelas Regras de Análise de Sementes (Brasil - Ministério da Agricultura, 1992).

\subsubsection{Rendimento}

Após a coleta de dados relativos às determinações de précolheita, procedeu-se a colheita das parcelas, avaliando-se a produção das três linhas centrais (parcela útil), transformando-se os dados de $\mathrm{Kg}^{\text {p.parcela }}{ }^{-1}$ para Kg.ha-1. 


\section{RESULTADOS E DISCUSSÃO}

Os experimentos foram conduzidos nos anos agrícolas de 1996 e 1997, sendo que para a época normal não foi verificado nenhuma restrição climatológica para o pleno estabelecimento e produção da cultura, que teve seu desenvolvimento acompanhado com base na escala fenológica de Fehr \& Caviness (1977). Por outro lado, na época safrinha, verificou-se condições ambientais mais limitantes, principalmente com relação à pluviosidade, o que levou à necessidade de suplementação hídrica através de irrigação. As médias de temperatura e precipitação total nas duas épocas podem ser vistas no gráfico um.

Os resultados da análise conjunta das épocas um e dois são apresentados a seguir.

Para os caracteres porcentagem de emergência e diâmetro da haste principal constatou-se efeito significativo de cultivares. $E$ também para os caracteres altura final de plantas e diâmetro da haste principal, efeito significativo de densidades, e para o caracter diâmetro da haste principal efeito significativo de épocas.

Para os caracteres altura final de planta, altura de inserção da primeira vagem, número de vagens no ápice das plantas, peso de 1000 sementes e rendimento, verificou-se efeito significativo de interação de cultivares com épocas. Constatou-se ainda para o caracter altura de inserção da primeira vagem, efeito significativo de interação de cultivares com densidades. 
Observou-se ainda para os caracteres peso de sementes por plantas, número total de sementes por planta e número total de vagens por planta, efeito significativo de interação de cultivares, densidades e épocas.

Os valores médios observados para os caracteres estudados, referentes aos cultivares e densidades, dado as épocas, que não atenderam a pressuposição do modelo matemático utilizado, foram agrupados e são apresentados na tabela 13.

\subsection{Porcentagem de emergência}

$\mathrm{Na}$ tabela 4, encontram-se os valores médios da porcentagem de emergência, observando-se que, para esse caracter, houve efeito de cultivares, no conjunto das épocas estudadas, constatando-se diferenças significativas entre os cultivares, com superioridade para o IAC-19. Conforme o esperado, essas diferenças devem-se à características intrínsecas a cada cultivar, provavelmente, ao nível de vigor das sementes. Embora não tenha sido objeto de estudo no presente trabalho, visualmente, também observou-se maior velocidade de emergência de plântulas do cultivar IAC-19 em relação aos demais.

\begin{tabular}{|c|c|c|}
\hline Tabela & \multicolumn{2}{|c|}{$\begin{array}{l}\text { 4. Valores médios de } \\
\text { porcentagem de emergência } \\
\text { dos cultivares IAC-12, IAC-17 e } \\
\text { IAC-19. Piracicaba-SP, } 1997\end{array}$} \\
\hline \multicolumn{2}{|c|}{ Cultivar } & Emergência (\%) \\
\hline \multicolumn{2}{|c|}{ IAC-12 } & $60,9 \quad c$ \\
\hline \multicolumn{2}{|c|}{ IAC-17 } & 68,7 b \\
\hline \multicolumn{2}{|c|}{ IAC-19 } & $78,9 a$ \\
\hline
\end{tabular}




\subsection{Altura final de planta}

Observou-se efeito de densidades, no conjunto das épocas estudadas, para o caracter altura final de planta (tabela 5), constatando-se diferença significativa entre a densidade 10 plantas $\mathrm{m}^{-1}$ e as demais.

Observou-se ainda uma redução nos valores, no sentido da maior densidade (30 plantas. $\mathrm{m}^{-1}$ ) para a menor (10 plantas. $\left.\mathrm{m}^{-1}\right)$.

Tabela 5. Valores médios de altura final de planta (AFP) em cinco densidades de semeadura. Piracicaba-SP, 1997

\begin{tabular}{cl}
\hline Densidade (plantas. $\left.\mathbf{m}^{-1}\right)$ & AFP $(\mathbf{c m})$ \\
\hline 10 & $58,33 \mathrm{~b}$ \\
15 & $64,04 \mathrm{a}$ \\
20 & $66,29 \mathrm{a}$ \\
25 & $66,37 \mathrm{a}$ \\
30 & $68,44 \mathrm{a}$ \\
\hline \hline
\end{tabular}

Médias com letras iguais não diferem estatisticamente.

Ainda para altura final de planta, verificou-se que houve efeito de interação de cultivares com épocas (tabela 6), mostrando diferenças significativas dos cultivares em cada época, sendo a época um sempre superior à época dois para os três cultivares. Esses resultados confirmam as observações de Miranda \& Mascarenhas (1986) quando afirmam que semeaduras de soja fora da época recomendada, podem determinar redução na altura das plantas e no rendimento.

Analisando o comportamento dos cultivares, para altura final de planta, dentro de cada época, observou-se que houve superioridade significativa do IAC-19 em ambas as épocas, e na época dois inferioridade 
significativa do IAC-17, provavelmente devido aos seus respectivos ciclos de maturação.

Tabela 6. Valores médios de altura final de plantas (AFP), altura de inserção da primeira vagem (APV), número de vagens no ápice (NVA), peso de 1000 sementes (P1000) e rendimento (REND) dos cultivares IAC-12, IAC-17 e IAC-19 em duas épocas de semeadura. Piracicaba-SP, 1997

\begin{tabular}{|c|c|c|c|c|c|c|}
\hline \multirow[t]{2}{*}{ Parâmetros } & \multirow[b]{2}{*}{ Épocas } & \multicolumn{5}{|c|}{ Cultivares } \\
\hline & & IAC-12 & \multicolumn{3}{|c|}{ IAC-17 } & IAC-19 \\
\hline AFP & E1 & 79,17 a $\mathrm{B}$ & 75,83 & $a$ & $B$ & 90,32 a $A$ \\
\hline$(\mathrm{cm})$ & E2 & 42,77 & 36,62 & b & C & 63,47 \\
\hline APV & E1 & 18,63 a $A$ & 19,91 & a $\mathrm{A}$ & & $13,47 \quad a$ \\
\hline$(\mathrm{cm})$ & E2 & $14,55 \quad b \quad B$ & 12,69 & $b$ & $\mathrm{~B}$ & $23,13 \quad b A$ \\
\hline \multirow[t]{2}{*}{ NVA } & E1 & 1,07 a $B$ & 2,07 & a $\mathrm{A}$ & & $1,07 \quad a$ \\
\hline & E2 & 0,67 a $A$ & 0,87 & b A & & 1,07 a $A$ \\
\hline P1000 & E1 & $146,19 a$ & 167,49 & $a$ & $B$ & 179,41 a $A$ \\
\hline (g) & E2 & $110,29 \quad b$ & 122,08 & $b$ & B & $141,27 \quad b A$ \\
\hline REND & E1 & 3317,9 a $A$ & 2841,7 & a & $B$ & 3193,15 a $A$ \\
\hline (kg/ha) & E2 & $835,9 \quad b \quad B$ & 674,1 & b & $B$ & 1438,1 \\
\hline
\end{tabular}
Médias com letras minúsculas iguais nas colunas, para cada variável, não diferem estatisticamente. Médias com letras maiúsculas iguais nas linhas, para cada variável, não diferem estatisticamente.

Observou-se um encurtamento no período relativo ao início da floração até a maturidade fisiológica, sendo que o IAC-17 (ciclo de maturação precoce), apresentou a maior redução (tabela 7). Dessa forma, cabe dizer que a fase do ciclo que sofre alteração, em função da época de semeadura, é aquela compreendida entre o início da floração e a maturidade fisiológica com as plantas mantendo suas características de juvenilidade próprias a cada cultivar. 
Tabela 7. Intervalo médio de dias entre a emergência (DAE), início da floração (R1) e maturidade fisiológica (R7) de três cultivares de soja de ciclo de maturação diferentes (precoce: IAC-17, semi-precoce: IAC-12 e médio: IAC-19) e em duas épocas de semeadura. Piracicaba, 1997

\begin{tabular}{ccccccc}
\hline Épocas & \multicolumn{2}{c}{ IAC-12 } & \multicolumn{2}{c}{ IAC-17 } & \multicolumn{2}{c}{ IAC-19 } \\
\cline { 2 - 7 } & DAE - R1 & R1 - R7 & DAE - R1 & R1 - R7 & DAE - R1 & R1 - R7 \\
\hline E1 & 46 & 64 & 46 & 64 & 46 & 68 \\
E2 & 49 & 49 & 44 & 43 & 52 & 56 \\
\hline \hline
\end{tabular}

\subsection{Altura de inserção da primeira vagem}

$\mathrm{Na}$ tabela 6, observou-se que houve efeito de interação de cultivares com épocas, para o caracter altura de inserção da primeira vagem, apresentando diferenças significativas entre cultivares dentro de épocas e entre as épocas dado os cultivares. Na época um, o cultivar IAC-19, apresentou a menor altura de inserção da primeira vagem, diferindo significativamente dos cultivares IAC-12 e IAC-17, porém estes não diferiram entre si. O mesmo não ocorreu para a época dois onde o IAC-19 apresentou a maior altura e o IAC-17 a menor.

O fato do cultivar IAC-19 ter apresentado a menor altura de inserção da primeira vagem na época um, contraria resultados de Garcia (1979), onde maiores valores de altura de inserção da primeira vagem e altura final de planta foram obtidos para os cultivares mais tardios. $\mathrm{Na}$ época dois, esses resultados mostraram que a altura de inserção da primeira vagem e a altura final de planta variaram de acordo com o ciclo de maturação dos cultivares, ou seja, com o aumento do ciclo de maturação ocorreu maior altura 
final de planta e maior altura de inserção da primeira vagem, concordando com esse mesmo autor.

A tabela 8 mostra que houve, para altura de inserção da primeira vagem, efeito de interação de cultivares com densidades, no conjunto das épocas estudadas, observando diferenças significativas entre as densidades para cada cultivar e entre os cultivares para cada densidade.

Para os cultivares IAC-12 e IAC-17 os maiores valores para altura de inserção da primeira vagem ocorreram na maior densidade (30 plantas. $\mathrm{m}^{-1}$ ) enquanto que para o cultivar IAC-19 esta foi observada na densidade de 15 plantas. $\mathrm{m}^{-1}$. Por outro lado, a menor altura, entre os três cultivares estudados, foi constatada na densidade de 10 plantas. $\mathrm{m}^{-1}$ para IAC-12, estando todos no entanto dentro da altura recomendada pela EMBRAPA (1996a) quando prescreve a altura mínima de $12 \mathrm{~cm}$, visando evitar maiores perdas na colheita (tabela 8).

Tabela 8. Valores médios para altura de inserção da primeira vagem (APV), em $\mathrm{cm}$, dos cultivares IAC-12, IAC-17 e IAC-19 em cinco densidades de semeadura. Piracicaba-SP, 1997

\begin{tabular}{|c|c|c|c|}
\hline \multirow{2}{*}{$\begin{array}{l}\text { Densidades } \\
\text { (plantas. } \mathrm{m}^{-1} \text { ) }\end{array}$} & \multicolumn{3}{|c|}{ Cultivares } \\
\hline & IAC-12 & IAC-17 & IAC-19 \\
\hline 10 & 12,07 & 13,88 a $A$ & 16,63 \\
\hline 15 & $15,67 \quad b \quad B$ & 17,12 a $B$ & 21,38 a $A$ \\
\hline 20 & 16,78 ab $A$ & 16,9 a $A$ & $15,82 \quad b A$ \\
\hline 25 & 18,22 ab $A$ & 16,33 a $A$ & 18,77 a $A$ \\
\hline 30 & 20,2 a $A$ & 17,27 a $A$ & 18,92 a $A$ \\
\hline
\end{tabular}

Médias com letras minúsculas iguais nas colunas, para cada variável, não diferem estatisticamente.

Médias com letras maiúsculas iguais nas linhas, para cada variável, não diferem estatisticamente. 


\subsection{Diâmetro da haste principal}

O caracter diâmetro da haste principal apresentou isoladamente efeitos de cultivar, densidades e épocas (tabelas 9, 10 e 11, respectivamente), no conjunto das épocas estudadas.

Pode-se observar na tabela 9, na qual se encontram os valores médios de diâmetro da haste principal dos cultivares, diferença significativa entre eles, sendo que o IAC-19 difere do IAC-17 porém, não difere do IAC-12 e este não difere do IAC-17. Nesse caso, essas diferenças devem-se ao ciclo de maturação, pois havendo mais dias de ciclo, há portanto mais tempo para o desenvolvimento da parte aérea das plantas, que se reflete também em maior diâmetro da haste principal.

\begin{tabular}{|c|c|}
\hline Cultivar & $\mathrm{DHP}(\mathrm{cm})$ \\
\hline IAC-12 & $0,52 a b$ \\
\hline IAC-17 & $0,50 \mathrm{~b}$ \\
\hline IAC-19 & $0,55 a$ \\
\hline
\end{tabular}

\begin{tabular}{l}
\hline \hline $\begin{array}{l}\text { Médias com letras iguais não diferem } \\
\text { estatisticamente. }\end{array}$ \\
\end{tabular}

Os efeitos de densidades apresentados na tabela 10, mostram que ocorreu redução nos valores no sentido das menores para as maiores, provavelmente, devido a uma maior competição entre plantas que se estabelece nas maiores populações. Nestas populações, devido a esse efeito 
de competição, ocorreu maior altura final de planta (tabela 5), porém os menores diâmetro da haste principal.

\begin{tabular}{ccc} 
Tabela 10. $\begin{array}{c}\text { Valores médios de diâmetro da haste } \\
\text { principal (DHP) em cinco densidades de } \\
\text { semeadura. Piracicaba-SP, }\end{array}$ \\
\hline \hline Densidade (plantas. $\mathbf{m}^{-1}$ ) & \multicolumn{2}{c}{ DHP (cm) } \\
\hline 10 & 0,60 & a \\
15 & 0,53 & $\mathrm{~b}$ \\
20 & 0,52 & bc \\
25 & 0,47 & $\mathrm{c}$ \\
30 & 0,49 & bc \\
\hline \hline
\end{tabular}

Médias com letras iguais não diferem estatisticamente.

Os valores médios de diâmetro da haste principal entre épocas de semeadura encontram-se na tabela 11, onde é possivel observar que a época um foi significativamente superior à época dois.

Tabela 11. Valores médios do diâmetro da haste principal (DHP) de plantas de soja em duas épocas de semeadura. Piracicaba-SP, 1997.

\begin{tabular}{cccc}
\hline Épocas & DHP $(\mathbf{c m})$ \\
\hline E1 & 0,65 a & \\
E2 & $0,40 \quad$ b & \\
\hline \hline Médias com letras & iguais não & diferem \\
estatisticamente. & & &
\end{tabular}




\subsection{Número final de nós vegetativos}

Os resultados referentes ao número final de nós vegetativos, para as épocas de semeadura normal e "safrinha", encontram-se na tabela 13.

$\mathrm{Na}$ tabela 13, observa-se que todos os cultivares apresentaram redução no número final de nós vegetativos da primeira para a segunda época de cultivo, especialmente o cultivar IAC-12.

Da mesma forma (tabela 6), para todos os cultivares houve redução na altura final de planta da época normal para a época safrinha.

Fazendo-se a relação entre a altura final e número final de nós vegetativos (tabela 12), obtém-se o comprimento médio de cada entrenó. Neste caso, também se observou que da primeira para a segunda época, todos os cultivares encurtaram a distância média entre os nós da haste principal.

Tabela 12. Comprimento médio $(\mathrm{cm})$ do entrenó de três diferentes cultivares de soja em duas épocas de semeadura. Piracicaba, 1997

\begin{tabular}{cccccc}
\hline Épocas & \multicolumn{3}{c}{ Cultivares } & Médias \\
& IAC-12 & IAC-17 & IAC-19 & \\
\hline E1 & 6,59 & 6,32 & 6,95 & 6,62 \\
E2 & 4,27 & 4,07 & 5,77 & 4,70 \\
\hline
\end{tabular}

Dessa forma, pode-se inferir que a redução na altura final de planta observada na época "safrinha", foi conseqüência do menor número de nós vegetativos formados e do encurtamento dos entrenós.

Nesse caso, os cultivares IAC-12 e IAC-17 foram os que mais reduziram o porte de suas plantas com o cultivo em ciclo de safrinha. 


\subsection{Número de ramificações por planta}

Entre épocas, o número de ramificações formadas por planta variou para todos os cultivares, em especial para o cultivar IAC-17 (tabela 13), - qual da época normal para a safrinha apresentou menor número de ramificações formadas por planta, da mesma forma que as plantas cresceram menos em altura.

Em ambas as épocas, observou-se para os três cultivares, diminuição no número de ramificações por planta com o aumento da densidade de plantas, associado com a maior altura final destas (tabela 6 e 13). Tal comportamento já era esperado, conforme descrito por Nakagawa et al. (1988), que obtiveram resultados semelhantes.

\subsection{Grau de acamamento}

O caracter grau de acamamento (Tabela 13) é apresentado sob a forma de notas, mostrando que não ocorreram variações acentuadas nas épocas de semeadura e população de plantas.

Os valores observados para o caracter grau de acamamento, nas duas épocas estudadas, estão dentro da faixa recomendável, situação considerada favorável para uma colheita mecanizada com menores perdas.

$\mathrm{Na}$ tabela 13, estão, ainda, os valores médios referentes aos cultivares e densidades, dado as épocas, dos caracteres número de ramificações, número de vagens chochas, número de vagens com 1, 2 e 3 sementes, número de sementes por vagem, e grau de acamamento, que foram agrupados, uma vez que não apresentaram distribuição normal e homogeneidade de variâncias, não satisfazendo às pressuposições do modelo matemático proposto para análise estatística, e dessa forma, serão discutidos sem o enfoque estatístico. 
Tabela 13. Valores médios do número final de nós vegetativos (Nfnv), número de ramificações (Nr), número de vagens chochas $(\mathrm{Nvc})$, número de vagens com 1 (Nv1s), 2 (Nv2s) e 3 (Nv3s) sementes, número de sementes por vagem (Nsv), e grau de acamamento (Acam) dos cultivares IAC-12, IAC17 e IAC-19 em diferentes densidades e duas épocas de semeadura (E1 e E2). Piracicaba-SP, 1997

\begin{tabular}{|c|c|c|c|c|c|c|c|c|c|}
\hline Cultivarl E1 & Dens. & Nfinv & $\mathrm{Nr}$ & Nvc & Nv1s & Nv2s & Nv3s & Nsv & Acam \\
\hline IAC - 12 & $\begin{array}{l}10 \\
15 \\
20 \\
25 \\
30\end{array}$ & $\begin{array}{l}12 \\
12 \\
12 \\
12 \\
13\end{array}$ & $\begin{array}{l}3 \\
2 \\
1 \\
2 \\
1\end{array}$ & $\begin{array}{l}7 \\
5 \\
2 \\
3 \\
6\end{array}$ & $\begin{array}{l}4 \\
3 \\
2 \\
2 \\
2\end{array}$ & $\begin{array}{l}49 \\
28 \\
19 \\
26 \\
24\end{array}$ & $\begin{array}{r}22 \\
12 \\
8 \\
11 \\
10\end{array}$ & $\begin{array}{l}2 \\
2 \\
2 \\
2 \\
2\end{array}$ & $\begin{array}{l}1 \\
1 \\
1 \\
2 \\
1\end{array}$ \\
\hline$I A C-17$ & $\begin{array}{l}10 \\
15 \\
20 \\
25 \\
30\end{array}$ & $\begin{array}{l}12 \\
12 \\
12 \\
12 \\
12 \\
12\end{array}$ & $\begin{array}{l}2 \\
5 \\
4 \\
4 \\
2 \\
3\end{array}$ & $\begin{array}{r}5 \\
12 \\
10 \\
6 \\
6 \\
9\end{array}$ & $\begin{array}{l}3 \\
4 \\
3 \\
3 \\
3 \\
2\end{array}$ & $\begin{array}{l}29 \\
41 \\
26 \\
25 \\
24 \\
25\end{array}$ & $\begin{array}{c}13 \\
6 \\
4 \\
5 \\
4 \\
5\end{array}$ & $\begin{array}{l}2 \\
1 \\
1 \\
1 \\
1 \\
1\end{array}$ & $\begin{array}{l}1 \\
1 \\
1 \\
1 \\
2 \\
2\end{array}$ \\
\hline$I A C-19$ & $\begin{array}{l}10 \\
15 \\
20 \\
25 \\
30 \\
\end{array}$ & $\begin{array}{l}12 \\
13 \\
13 \\
14 \\
13 \\
13 \\
\end{array}$ & $\begin{array}{l}4 \\
3 \\
2 \\
3 \\
1 \\
2 \\
\end{array}$ & $\begin{array}{r}9 \\
7 \\
5 \\
8 \\
8 \\
11 \\
\end{array}$ & $\begin{array}{l}3 \\
3 \\
4 \\
4 \\
4 \\
3 \\
\end{array}$ & $\begin{array}{l}28 \\
32 \\
27 \\
34 \\
23 \\
25 \\
\end{array}$ & $\begin{array}{l}5 \\
8 \\
6 \\
8 \\
5 \\
6 \\
\end{array}$ & $\begin{array}{l}1 \\
2 \\
2 \\
2 \\
1 \\
1 \\
\end{array}$ & $\begin{array}{l}1 \\
2 \\
2 \\
2 \\
2 \\
2 \\
\end{array}$ \\
\hline Média & & 13 & 2 & 8 & 4 & 28 & 7 & 2 & 2 \\
\hline Cultivar/ E2 & Dens. & Nfnv & $\mathrm{Nr}$ & Nvc & Nv1s & Nv2s & Nv3s & Nsv & Acam \\
\hline$I A C-12$ & $\begin{array}{l}10 \\
15 \\
20 \\
25 \\
30\end{array}$ & $\begin{array}{l}10 \\
11 \\
10 \\
11 \\
10 \\
\end{array}$ & $\begin{array}{l}2 \\
2 \\
2 \\
1 \\
1 \\
\end{array}$ & $\begin{array}{l}2 \\
1 \\
0 \\
1 \\
1 \\
\end{array}$ & $\begin{array}{l}1 \\
1 \\
1 \\
1 \\
1 \\
\end{array}$ & $\begin{array}{l}9 \\
7 \\
9 \\
7 \\
6 \\
\end{array}$ & $\begin{array}{r}13 \\
9 \\
10 \\
7 \\
6\end{array}$ & $\begin{array}{l}2 \\
2 \\
2 \\
2 \\
2 \\
\end{array}$ & $\begin{array}{l}1 \\
2 \\
1 \\
2 \\
1 \\
\end{array}$ \\
\hline $\mid A C-17$ & $\begin{array}{l}10 \\
15 \\
20 \\
25 \\
30 \\
\end{array}$ & $\begin{array}{c}10 \\
10 \\
8 \\
9 \\
9 \\
8 \\
\end{array}$ & $\begin{array}{l}2 \\
2 \\
1 \\
1 \\
0 \\
0 \\
\end{array}$ & $\begin{array}{l}1 \\
1 \\
1 \\
1 \\
1 \\
0 \\
\end{array}$ & $\begin{array}{l}1 \\
4 \\
3 \\
3 \\
3 \\
3 \\
\end{array}$ & $\begin{array}{r}8 \\
11 \\
6 \\
6 \\
5 \\
6 \\
\end{array}$ & $\begin{array}{l}9 \\
7 \\
4 \\
5 \\
3 \\
3 \\
\end{array}$ & $\begin{array}{l}2 \\
2 \\
2 \\
2 \\
2 \\
2 \\
\end{array}$ & $\begin{array}{l}1 \\
2 \\
1 \\
2 \\
2 \\
1 \\
\end{array}$ \\
\hline$I A C-19$ & $\begin{array}{l}10 \\
15 \\
20 \\
25 \\
30 \\
\end{array}$ & $\begin{array}{c}9 \\
12 \\
12 \\
11 \\
11 \\
11 \\
\end{array}$ & $\begin{array}{l}1 \\
3 \\
2 \\
1 \\
1 \\
1 \\
\end{array}$ & $\begin{array}{l}1 \\
2 \\
1 \\
1 \\
1 \\
1 \\
\end{array}$ & $\begin{array}{l}3 \\
3 \\
2 \\
1 \\
1 \\
1 \\
\end{array}$ & $\begin{array}{r}7 \\
5 \\
11 \\
12 \\
10 \\
9 \\
\end{array}$ & $\begin{array}{l}4 \\
9 \\
8 \\
5 \\
5 \\
4 \\
\end{array}$ & $\begin{array}{l}2 \\
2 \\
2 \\
2 \\
2 \\
2 \\
\end{array}$ & $\begin{array}{l}2 \\
1 \\
2 \\
3 \\
2 \\
3 \\
\end{array}$ \\
\hline Média & & 11 & 2 & 1 & 2 & 9 & 6 & 2 & 2 \\
\hline
\end{tabular}

OBS.: Dens. $=$ densidade $\left(\right.$ plantas. $\left.\mathrm{m}^{-1}\right)$ 


\subsection{Número total de vagens por planta}

Houve efeito significativo de interação de cultivar, densidade e épocas para o caracter número total de vagens por planta. Os dados referentes ao número total de vagens por planta encontram-se na tabela 14, e mostram que ocorreram diferenças significativas para as densidades e as épocas estudadas. Observa-se ainda que o cultivar IAC-19 foi o que apresentou as menores variações nos resultados, bem como IAC-12 obteve o maior número total de vagens por planta na época um e na densidade 10 plantas. $\mathrm{m}^{-1}$.

$\mathrm{Na}$ época um foram obtidas cerca de duas vezes ou mais vagens, em relação à época dois. Provavelmente, as condições ecológicas características de cada época, tenham sido responsáveis pela drástica redução na produção de vagens e, consequentemente, no rendimento ocorrida na época dois, em relação à época um. 
Tabela 14. Valores médios do número total de vagens por planta (NTV), número total de sementes por planta (NTS) e peso de sementes por planta dos cultivares IAC-12, IAC-17 e IAC-19 em diferentes densidades e duas épocas de semeadura. Piracicaba-SP, 1997

\begin{tabular}{|c|c|c|c|c|c|c|c|}
\hline \multirow[b]{2}{*}{ Cv. } & \multirow[b]{2}{*}{ Dens } & \multicolumn{2}{|c|}{ NTV } & \multicolumn{2}{|c|}{ NTS } & \multicolumn{2}{|c|}{ Peso de sementes (g) } \\
\hline & & Época 1 & Época 2 & Época 1 & Época 2 & Época 1 & Epoca 2 \\
\hline & 10 & 82,3 a $\quad A$ & 24,3 a B & 147,0 a & 48,3 a $B$ & 21,4 a $A$ & $6,1 \mathrm{a} \quad \mathrm{B}$ \\
\hline & 15 & 48,0 b $A$ & 19,0 a B & 82,3 b $A$ & 38,3 a $B$ & 11,8 b A & 4,8 a $B$ \\
\hline \multirow[t]{3}{*}{ IAC-12 } & 20 & $31,3 \quad c A$ & 20,7 a A & $56,3 \quad c A$ & 41,3 a $A$ & 8,1 b A & 5,1 a $A$ \\
\hline & 25 & 42,3 bc $A$ & 15,7 a $B$ & 74,0 bc $A$ & 30,0 a $B$ & 11,0 b A & 3,9 a $B$ \\
\hline & 30 & 41,7 bc $A$ & 14,0 a $B$ & 68,3 bc $A$ & 26,7 a $B$ & 8,6 b A & 3,8 a $B$ \\
\hline \multirow[t]{3}{*}{ Média } & & 49,3 & 19,1 & 85,8 & 37,3 & 12,4 & 5,1 \\
\hline & 10 & 63,0 a $A$ & 23,7 a $B$ & 87,0 a $A$ & 47,7 a $B$ & 14,2 a $A$ & $8,2 \mathrm{a} \quad \mathrm{B}$ \\
\hline & 15 & 43,3 b A & 13,7 a $B$ & 59,3 b A & 24,3 a $B$ & 9,5 b A & 3,2 b B \\
\hline \multirow[t]{3}{*}{ IAC-17 } & 20 & 39,0 b A & 15,0 a $B$ & 56,3 b A & 27,0 a $B$ & 9,3 b A & 3,6 b B \\
\hline & 25 & 37,3 b A & 12,3 a $B$ & 52,7 b A & 21,7 a $B$ & 8,6 b A & 2,7 b B \\
\hline & 30 & 40,3 b A & 11,3 a $\mathrm{B}$ & 53,7 b A & 21,3 a $B$ & 8,7 b A & 2,8 b B \\
\hline \multirow[t]{3}{*}{ Média } & & 44,6 & 15,2 & 61,8 & 28,4 & 10,1 & 4,1 \\
\hline & 10 & 49,3 a $A$ & 28,3 a $B$ & 79,3 ab $A$ & 59,0 a $A$ & 13,4 ab $A$ & 10,7 a $\quad A$ \\
\hline & 15 & 43,0 a $A$ & $21,3 a b$ B & 67,7 ab $A$ & 43,3 a $B$ & $12,2 a b A$ & 9,4 ab $A$ \\
\hline \multirow[t]{3}{*}{ IAC-19 } & 20 & 53,0 a $A$ & 18,3 ab B & 81,0 a $A$ & 35,3 b B & 14,3 a $A$ & 7,1 abc $B$ \\
\hline & 25 & 41,0 a $A$ & 16,7 ab B & 55,0 b A & $32,7 \quad b A$ & 9,5 b A & 5,1 bc $A$ \\
\hline & 30 & 45,0 a $A$ & 14,7 b B & 55,7 b A & 28,7 b B & 9,9 b A & $C B$ \\
\hline Média & & 46,3 & 19,9 & 67,7 & 39,8 & 11,9 & 7,3 \\
\hline
\end{tabular}

Médias com letras minúsculas iguais nas colunas, para cultivares, não diferem estatisticamente.

Médias com letras maiúsculas iguais nas linhas, para cada variável, nảo diferem estatisticamente. Obs.: Dens. $=$ densidade $\left(\right.$ plantas $\left.\mathrm{m}^{-1}\right), \mathrm{Cv}$. $=$ cultivar

$\mathrm{Na}$ tabela 15 são apresentados os resultados referentes ao número médio de vagens por nó vegetativo, obtidos pela relação entre o número total de vagens e o número final de nós vegetativos. Observa-se que o cultivar IAC-12 obteve os maiores valores, nas duas épocas estudadas, indicando ser ele o mais eficiente, dentre os três, no caráter em questão, e que, 
provavelmente, tal característica seja intrínseca a cada cultivar, independente da época de semeadura.

O cultivar IAC-19, por outro lado, foi o que apresentou a menor variação entre as épocas, ficando a época dois com os menores resultados.

Tabela 15. Número médio de vagens por nó vegetativo apresentados por três diferentes cultivares de soja nas épocas normal (E1) de semeadura e "safrinha" (E2). Piracicaba, 1997

\begin{tabular}{cccccc}
\hline \hline Épocas & \multicolumn{4}{c}{ Cultivares } & Médias \\
& IAC-12 & IAC-17 & IAC-19 & \\
\hline E1 & 4,1 & 3,7 & 3,6 & 3,8 \\
E2 & 1,9 & 1,7 & 1,8 & 1,8 \\
\hline \hline
\end{tabular}

\subsection{Número de vagens no ápice por planta}

Os resultados médios obtidos para esse caracter são apresentados na tabela 6 , onde se verifica efeito de interação de cultivares com épocas, apresentando diferenças significativas do cultivar IAC-17 em relação aos demais dentro da época normal de semeadura. $\mathrm{Na}$ época "safrinha", observou-se um menor número de vagens no ápice.

\subsection{Número de vagens chochas por planta}

O cultivar IAC-12 mostrou resultados menores, para número de vagens chochas, que os demais cultivares na época um (tabela 13). $\mathrm{Na}$ época dois os cultivares apresentaram resultados semelhantes entre si e muito inferiores com relação à época um, mostrando que a queda no rendimento 
ocorrida na época dois é em função da redução na produção do total de vagens, e não em conseqüência de um aumento no número de vagens chochas.

\subsection{Número diferenciado de sementes por vagem}

Com relação ao número de vagens apresentando uma semente (tabela 13), os resultados mostraram-se muito próximos para os cultivares e as densidades na época um. Porém na época dois, os cultivares apresentaram maiores variações, sendo para o IAC-12 os menores valores. Destaca-se ainda um maior número de vagens com uma semente na época um em relação à época dois, sendo contudo semelhantes no cultivar IAC-17.

O número de vagens apresentando duas sementes (tabela 13), mostra variações para os cultivares e as densidades entre as épocas e dentro de cada época. Notando-se uma redução na época dois em relação a época um. Observa-se entretanto, que guardando as proporções, quanto ao número de vagens produzidos pelos cultivares nas duas épocas, o número de sementes por vagem praticamente não variou, ficando em torno de 2, com ressalva para o IAC-17 na época um, que apresentou em média 1 semente por vagem.

Os dados referentes ao número de vagens apresentando três sementes (tabela 13), mostram que os maiores valores ocorreram no cultivar IAC-12 nas duas épocas estudadas. Esse resultado associado à maior eficiência na produção de vagens por nó vegetativo, apresentada pelo mesmo cultivar na tabela 15 mostra o maior potencial de produção deste cultivar. Observa-se ainda uma redução no número de vagens com três sementes na época dois em relação a época um.

Outro aspecto observado, para a variável número de vagens apresentando três sementes, é que na época dois a relação desta com a 
variável número de vagens apresentando duas sementes, tornou-se mais equilibrada, mostrando valores menos discrepantes que na época um, tendo sido ainda, superior em algumas densidades.

\subsection{Número total de sementes por planta}

Para o caracter número total de sementes por planta, houve efeito significativo de interação de cultivar, densidade e épocas. Os dados referentes ao número total de sementes por planta podem ser vistos na tabela 14 , e mostram que houve diferenças significativas dos cultivares dado as densidades dentro e entre as épocas. Verifica-se ainda que houve maior produção de sementes na época de semeadura normal, em relação à época de semeadura "safrinha". As menores diferenças entre as épocas foram obtidas pelo cultivar IAC-19 de ciclo de maturação médio.

Observa-se também que os valores do número total de sementes por planta apresentados foram sempre superiores na densidade 10 plantas. $\mathrm{m}^{-1}$, bem como o resultado apresentado por IAC-12 nesta densidade na época um, foi surpreendentemente superior aos demais, isto, provavelmente, devido a uma melhor adaptação desse cultivar nas condições de semeadura em época normal. De acordo com esses resultados é possível sugerir uma redução na população de plantas para este cultivar, gerando economia de sementes combinada com um aumento na produção, resultando em maior rendimento econômico.

O número médio de sementes por nó vegetativo (tabela 16), obtido pela relação entre o número total de sementes e o número final de nós vegetativos, mostra que o cultivar IAC-12 apresentou o maior valor na época um e também na época dois, juntamente com o IAC-19, demonstrando mais uma vez sua melhor eficiência. 
Tabela 16. Número médio de sementes por nó vegetativo de três diferentes cultivares de soja semeados nas épocas normal ( $E 1)$ de semeadura e "safrinha" (E2). Piracicaba, 1997

\begin{tabular}{ccccc}
\hline Épocas & \multicolumn{3}{c}{ Cultivares } & Médias \\
& IAC-12 & IAC-17 & IAC-19 & \\
\hline E1 & 6,9 & 5,2 & 5,1 & 5,7 \\
E2 & 3,6 & 3,3 & 3,6 & 3,5 \\
\hline \hline
\end{tabular}

\subsection{Número de sementes por vagem}

A tabela 13 apresenta o número de sementes por vagem. Pode-se observar que ocorreram variações para o cultivar IAC-17 dentro e entre as épocas. Embora esta seja uma característica varietal, as oscilações ocorridas para este cultivar, podem ser em resposta variável às épocas de semeadura, uma vez que o número médio de duas sementes por vagem obtidos nas condiçōes do experimento, representa o esperado para a cultura da soja.

Parece haver uma certa compensação na época de semeadura "safrinha", observando-se um aumento no número de sementes por vagem, que vai se refletir no número total de sementes, em comparação com a época normal de semeadura, muito embora o número total de vagens tenha sido menor na época dois (tabela 14).

\subsection{Peso de sementes por planta}

O caracter peso de sementes por planta, apresentado na tabela 14, mostrou efeito significativo de interação de cultivar, densidade e épocas, evidenciando esse efeito para o cultivar IAC-17. No entanto, o cultivar IAC-12 
não apresentou diferença significativa entre as épocas para a densidade 20 plantas. $m^{-1}$, enquanto que para o $\mid A C-19$ essas diferenças não foram observadas nas densidades 10,15 e 25 plantas. $\mathrm{m}^{-1}$. Isso mostra que o IAC-19 foi o cultivar, entre os três estudados, que sofreu menor variação no peso de sementes entre as duas épocas de semeadura estudadas, assim como com relação ao número de sementes por nó vegetativo (tabela 16), número de vagens por nó vegetativo (tabela 15) e comprimento dos entrenós (tabela 12), permitindo considerá-lo o cultivar, dentre os três estudados, mais eficiente frente à semeadura em "safrinha". De uma maneira geral, as menores densidades apresentaram os maiores pesos de sementes, resultados estes, também obtidos por Nakagawa et al. (1987).

Observa-se ainda que houve uma redução no peso total de sementes por planta, na época dois em relação à época um, em todos os cultivares estudados.

A tabela 17 mostra o peso médio de 1 semente obtido pela relação entre peso de sementes por planta e número total de sementes por planta, onde observou-se que houve uma redução nos valores para os cultivares IAC-12 e IAC-17, na época dois em relação à época um, porém o IAC-19 mostrou uma notável capacidade de aumentar o peso de suas sementes na época "safrinha", nas densidades de 10, 15 e 20 plantas. $\mathrm{m}^{-1}$, talvez como uma forma de compensar as reduções nos valores acima citados, uma vez que a planta não conseguiu mantê-los estáveis entre as épocas de semeadura estudadas. 
Tabela 17. Peso médio $(\mathrm{mg})$ de 1 semente dos cultivares IAC-12, IAC-17 e IAC-19 em diferentes densidades e duas épocas de semeadura. Piracicaba-SP, 1997

\begin{tabular}{|c|c|c|c|}
\hline \multirow[b]{2}{*}{ Cultivares } & \multirow[b]{2}{*}{ Densidades } & \multicolumn{2}{|c|}{$\begin{array}{c}\text { Peso médio de } 1 \text { semente } \\
\text { (mg) }\end{array}$} \\
\hline & & Época 1 & Época 2 \\
\hline \multirow{5}{*}{ IAC-12 } & 10 & 145,6 & 127,0 \\
\hline & 15 & 143,4 & 125,3 \\
\hline & 20 & 143,9 & 123,5 \\
\hline & 25 & 148,7 & 130,0 \\
\hline & 30 & 125,9 & 142,3 \\
\hline \multirow[t]{3}{*}{ Média } & & 141,7 & 130,0 \\
\hline & 10 & 163,2 & 171,9 \\
\hline & 15 & 160,2 & 131,7 \\
\hline \multirow[t]{3}{*}{ IAC-17 } & 20 & 165,2 & 133,3 \\
\hline & 25 & 163,2 & 124,4 \\
\hline & 30 & 162,0 & 131,5 \\
\hline \multirow[t]{3}{*}{ Média } & & 162,8 & 138,6 \\
\hline & 10 & 169,0 & 181,4 \\
\hline & 15 & 180,2 & 217,1 \\
\hline \multirow[t]{3}{*}{ IAC-19 } & 20 & 176,5 & 201,1 \\
\hline & 25 & 172,7 & 156,0 \\
\hline & 30 & 177,7 & 146,3 \\
\hline Média & & 175,2 & 180,4 \\
\hline
\end{tabular}

\subsection{Peso de 1.000 sementes}

O caracter peso de 1000 sementes (tabela 6), apresentou efeito de interação de cultivares com épocas verificando-se diferenças significativas entre os cultivares dentro de épocas e entre as épocas dentro de cada cultivar, sendo que o IAC-19 foi maior que o IAC-17 e este maior que o IAC-12, nas 
duas épocas estudadas. Verificou-se ainda, que IAC-19 mostrou a menor variação entre as épocas.

Constatou-se que o cultivar IAC-12 apresentou os menores pesos de 1000 sementes nas duas épocas, no entanto, na época de semeadura normal, apresentou rendimento superior aos demais cultivares (tabela 6).

Observa-se ainda que os maiores valores foram obtidos na época de semeadura normal, para todos os cultivares. Isso mostra que as alterações ocorridas nos componentes da produção em função de época de semeadura refletiram na variável peso de 1000 sementes, bem como no número total de sementes e consequentemente no rendimento final.

\subsection{Rendimento}

Os valores médios de produção de grãos em $\mathrm{Kg}_{\text {h.ha }}{ }^{-1}$ são apresentados na tabela 6, onde verifica-se efeito de interação de cultivar com época, havendo diferenças significativas para cultivares dentro de cada época e entre as épocas.

Como pode ser visto, na época de semeadura normal, verificaramse os maiores rendimentos, onde os cultivares puderam, teoricamente, demonstrar todo o seu potencial produtivo, sem contudo, diferirem significativamente quanto as densidades, concordando com resultados encontrados por Nakagawa et al. (1986) em semeaduras realizadas nessa mesma época. O cultivar IAC-12, mesmo não apresentando uma diferença significativa em relação ao IAC-19, mostrou um melhor resultado, sendo superior e diferindo significativamente do cultivar IAC-17, que apresentou os menores rendimentos. Entretanto, na época de semeadura "safrinha", o cultivar IAC-19 foi superior, diferindo significativamente dos demais. Essas diferenças mostram que é possível manejar cultivares, de acordo com seu ciclo de maturação, visando obter-se ganhos em produtividade, para cada época. 
Comparando-se o efeito dessa interação de cultivares com épocas, constatou-se que a superioridade da época de semeadura normal em relação à "safrinha", foi determinada pelas condições ambientais, durante as fases fenológicas, influenciando os componentes de produção e comprometendo o rendimento final na época dois.

$\mathrm{Na}$ época de semeadura "safrinha", observa-se o melhor comportamento do cultivar de ciclo de maturação médio (IAC-19), podendo ser uma opção para esta época de semeadura no estado de São Paulo. Esse resultado está de acordo com EMBRAPA (1996a) ao afirmar que cultivares de ciclo de maturação médio a semi-tardio tem maiores potenciais de rendimento nessa época de semeadura.

\subsection{Considerações Gerais}

Em época normal de semeadura de soja, todos os cultivares apresentaram elevado rendimento, acima de $2.500 \mathrm{~kg} \mathrm{ha}^{-1}$, com destaque para os cultivares IAC-12 e IAC-19 como os mais produtivos. A superioridade da época de semeadura normal em relação à "safrinha", foi determinada pelas condições ambientais, durante as fases fenológicas, influenciando os componentes de produção e comprometendo o rendimento final na época dois. O cultivar IAC-12 de ciclo semi-precoce, apresentou elevados rendimentos com menores populações de plantas, 200.000 a 300.000 plantas por hectare, definidas, respectivamente, pelas densidades de 10 a 15 plantas por metro.

De acordo com o gráfico um, observou-se a necessidade de irrigação na época "safrinha", uma vez que a cultura da soja nessa época de semeadura seria inviável, pois a soma dos totais acumulados de precipitação no período (março - junho) de $274,4 \mathrm{~mm}$, não atende às necessidades pluviométricas mínimas para a soja que estão segundo EMBRAPA (1996a) entre $450-800 \mathrm{~mm}$. 
Da época normal para a época de safrinha, as plantas de soja diminuem de tamanho, devido à redução no comprimento do entrenó e à formação de menor número de nós vegetativos na haste principal, bem como se reduzem o número total de vagens e de sementes formadas, as quais também diminuem em massa.

A associação de precocidade de ciclo com juvenilidade longa em um cultivar de soja como IAC-17, não garante a manutenção de alta produtividade e de boa altura de planta para a colheita em épocas de semeadura muito tardias, como no caso da época de safrinha.

$\mathrm{Na}$ tentativa de recomendação de um cultivar para o estado de São Paulo em época de semeadura normal, os resultados obtidos, indicaram o cultivar IAC-12, uma vez que apresentou os maiores rendimentos. Para a época "safrinha", esses resultados permitem recomendar o cultivar IAC-19, de ciclo de maturação médio como a melhor opção, havendo contudo, a necessidade de desenvolvimento de cultivares específicos para essa época de semeadura.

Independente da época de semeadura, quanto maior a densidade de plantas de soja na linha, maior a altura final das plantas, menor o diâmetro da haste principal, menor o número de ramificações por planta, menor 0 número total de vagens e de sementes formadas e menor 0 peso das sementes.

As perdas ocorridas da época normal para a época de safrinha foram condicionadas pela diminuição no número de vagens, sementes formadas por planta e pela menor massa de semente, sendo que a perda no rendimento, foi variável conforme o cultivar utilizado, observando $76 \%$ para IAC-17 (precoce), 75\% para IAC-12 (semi-precoce) e 55\% para IAC-19 (médio). 
Com relação a emergência de plantas, constatou-se diferenças significativas entre os cultivares, devido às características intrínsecas de cada um quanto ao vigor de sementes, com superioridade do IAC 19.

A altura final de plantas foi influenciada pela densidade, observando-se uma redução no sentido da maior para a menor, havendo ainda efeito de interação de cultivares com épocas, mostrando diferenças significativas em cada época, sendo a época um sempre superior a época dois para os três cultivares, destacando-se a superioridade do IAC-19 em ambas as épocas.

Gráfico 1. Médias de temperatura e precipitação total nas épocas de semeadura normal e de "safrinha"

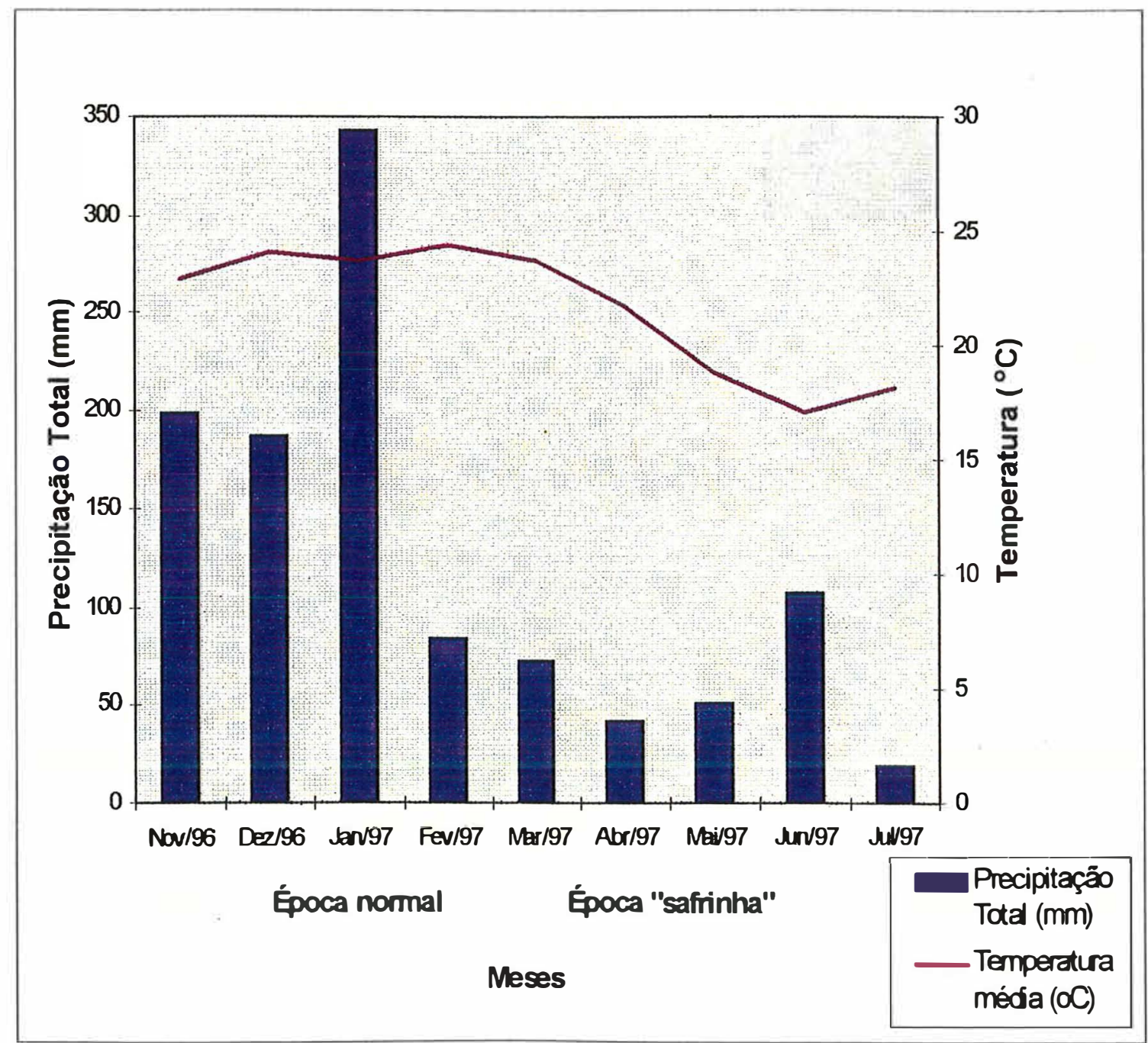


A altura de inserção da primeira vagem, mesmo sendo característica de cada cultivar, foi influenciada pela época e pela densidade, no entanto, permaneceu dentro do limite estabelecido visando evitar maiores perdas na colheita.

O caracter diâmetro da haste principal apresentou isoladamente efeitos de cultivar, densidades e épocas, sendo que os valores médios na época um foram significativamente superiores à época dois. Por outro lado, nas maiores densidades, as plantas apresentaram os menores diâmetros.

Em ambas as épocas, o número de ramificações por planta variou para todos os cultivares, ocorrendo diminuição, com o aumento da densidade de plantas.

O grau de acamamento não foi influenciado pelas épocas de semeadura e pela população.

O número total de vagens por planta foi influenciado pelo cultivar, densidade e épocas de semeadura. $\mathrm{Na}$ época um, foram obtidas cerca de duas vezes ou mais vagens que na época dois, sendo que o cultivar IAC-19 apresentou as menores diferenças entre épocas, enquanto que o IAC-12, os maiores valores médios de vagens por nó vegetativo.

Os resultados médios obtidos para o número de vagens no ápice por planta, mostram que o cultivar IAC-17 foi significativamente superior aos demais na época um. $\mathrm{Na}$ época "safrinha" observou-se um menor número de vagens no ápice.

Com relação ao número de vagens chochas por planta, a época um apresentou os maiores resultados em relação à época dois.

Embora tenha havido predominância do número de vagens com duas sementes em ambas as épocas, na época um esse número foi superior.

Houve efeito significativo de interação de cultivar, densidade e épocas de semeadura para a variável número total de sementes por planta, 
ocorrendo maior produção de sementes na época um e na densidade de 10 plantas. $\mathrm{m}^{-1}$. com destaque para o cultivar IAC-12.

$\mathrm{Na}$ época dois, verificou-se uma redução no peso total de sementes por planta, para todos os cultivares estudados. No entanto, o cultivar IAC-19 foi o que sofreu a menor variação neste peso, nas duas épocas, assim como com relação ao número de sementes por nó vegetativo, número de vagens por nó vegetativo e comprimento dos entrenós, permitindo considerá-lo o cultivar, dentre os três estudados, mais eficiente frente à semeadura em "safrinha".

Para peso de 1000 sementes, os maiores valores foram obtidos na época um, em todos os cultivares. Houve diferenças significativas entre os cultivares dentro de épocas e entre as épocas dentro de cada cultivar, sendo que o IAC-19 foi maior que o IAC-17 e este maior que o IAC-12, nas duas épocas estudadas.

O rendimento mostrou diferenças significativas para os cultivares dentro de cada época e entre as épocas, sendo constatados os maiores rendimentos na época um, onde o cultivar IAC-12, mesmo não apresentando uma diferença significativa em relação ao IAC-19, apresentou o melhor resultado, enquanto que na época dois, o cultivar IAC-19 foi significativamente superior aos demais. 


\section{CONCLUSŌES}

- nas condições em que foram conduzidos os experimentos, a semeadura de soja em época safrinha sem o uso de irrigação, toma-se inviável.

- a redução no ciclo da soja observada na época de semeadura safrinha, ocorreu principalmente na fase reprodutiva.

- em época de safrinha, o cultivar IAC-19, apresentou 0 melhor desempenho e maior rendimento de grãos. 
ANEXOS 


\section{A1. QUADRO DA ANÁLISE DA VARIÂNCIA DA ÉPOCA UM}

\begin{tabular}{|l|c|}
\hline \multicolumn{1}{|c|}{ Fonte de Variação } & GL \\
\hline Blocos & 2 \\
\hline Tratamentos (cultivares $\times$ densidades) & 14 \\
\hline Resíduo & 28 \\
\hline Total & 44 \\
\hline
\end{tabular}

A2. QUADRO DA ANÁLISE DA VARIÂNCIA DA ÉPOCA DOIS

\begin{tabular}{|l|c|}
\hline \multicolumn{1}{|c|}{ Fonte de Variação } & GL \\
\hline Blocos & 2 \\
\hline Tratamentos (cultivares $\times$ densidades) & 14 \\
\hline Resíduo & 28 \\
\hline Total & 44 \\
\hline
\end{tabular}


A3. QUADRO DA ANÁLISE DE VARIÂNCIA CONJUNTA DAS ÉPOCAS

\begin{tabular}{|l|c|}
\hline \multicolumn{1}{|c|}{ Fonte de Variação } & GL \\
\hline Blocos (épocas) & 4 \\
\hline Épocas & 1 \\
\hline Cultivar & 2 \\
\hline Épocas x Cultivar & 2 \\
\hline Densidade & 4 \\
\hline Épocas x Densidade & 4 \\
\hline Cultivar x Densidade & 8 \\
\hline Épocas x Cultivar x densidade & 8 \\
\hline Resíduo & 56 \\
\hline Total & 89 \\
\hline
\end{tabular}




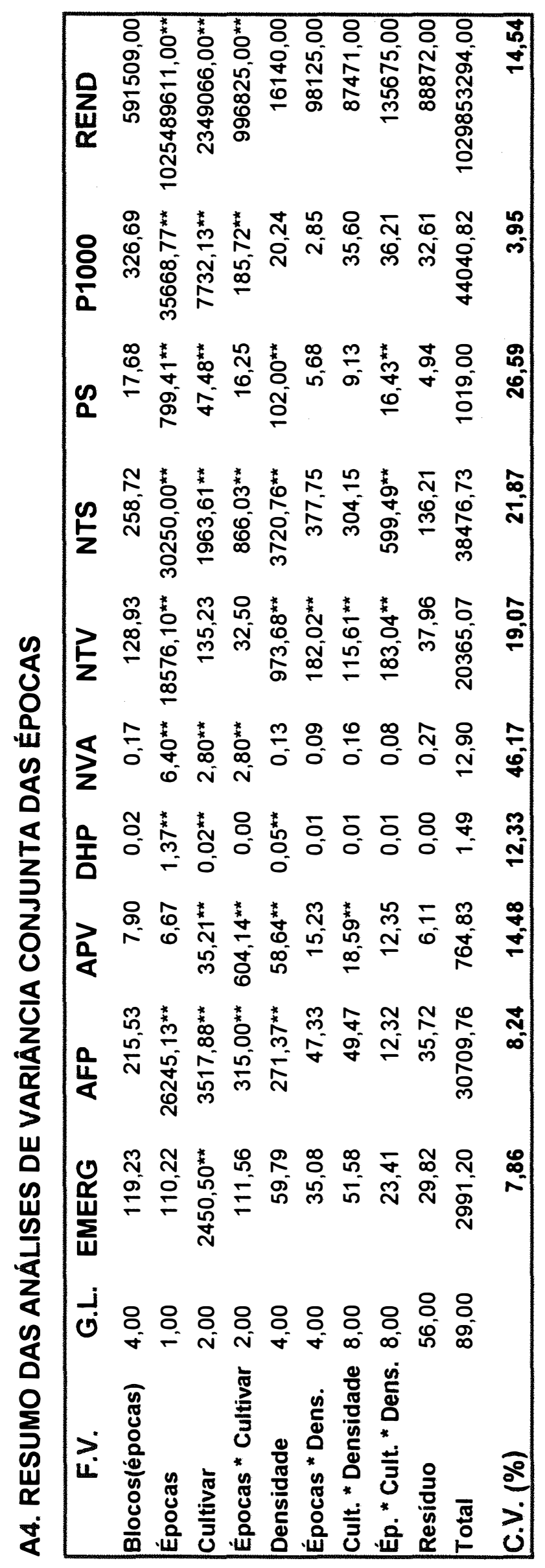




\section{REFERÊNCIAS BIBLIOGRÁFICAS}

BERGAMASCHI, H.; BERLATO, M.A.; WESTPHALEM, S.L. Épocas de semeadura de soja no RS: avaliação e interpretação dos ensaios ecológicos da soja. IPAGRO Informa, v.18, p.7-14, 1977.

BHERING, M.C. Influência de épocas de plantio sobre algumas características agronômicas e qualidade das sementes de soja (Glycine max (L.) Merrill). Viçosa, 1989. 57p. Dissertação (M.S.) - Universidade Federal de Viçosa.

BRASIL. Ministério da Agricultura. Regras para análise de sementes. Brasília: LANARVISNDA, 1992. 365p.

BUENO, L.C.S.; SEDIYMA, C.S.; VIEIRA, C. Efeitos do espaçamento, densidade e época de plantio sobre duas variedades de soja. Experientiae, v. 20, n.10, p.263-287, 1975.

CÂMARA, G.M.S. Efeito do fotoperíodo e da temperatura no crescimento, florescimento e maturação de cultivares de soja (Glycine max (L.) Merrill). Viçosa, 1991. 266p. Tese (Doutorado) - Universidade Federal de Viçosa.

CÂMARA, G.M.S. Ecofisiologia da cultura da soja. In: CÂMARA, G.M.S.; MARCOS FILHO, J.; OLIVEIRA, E.A.M. (Org.). Simpósio sobre a cultura e produtividade da soja. Anais. Piracicaba, FEALQ, 1992, cap.9, p.129-42. 
COSTA VAL, W.M.; BRANDÃO, S.S.; GALVÃO, J.D.; GOMES, F.R. Efeito do espaçamento entre fileiras sobre a produção e outras características agronômicas da soja. Experientiae, v.12, n.12, p.431-474, 1971.

EMPRESA BRASILEIRA DE PESQUISA AGROPECUÁRIA. Centro Nacional de Pesquisa da Soja. Recomendações técnicas para a cultura da soja no Paraná 1994/95. Cascavel, OCEPAR/EMBRAPA, CNPSo, 1994. 140p. (OCEPAR. Boletim Técnico, 36).

EMPRESA BRASILEIRA DE PESQUISA AGROPECUÁRIA. Centro Nacional de Pesquisa da Soja. Recomendações técnicas para a cultura da soja na região central do Brasil 1996/97. Londrina, 1996a. 149p. (EMBRAPACNPSo. Documentos, 88).

EMPRESA BRASILEIRA DE PESQUISA AGROPECUÁRIA. Centro Nacional de Pesquisa da Soja. Adubação fosfatada e potássica para a sucessão soja-trigo em latossolo roxo distrófico sob semeadura direta. Londrina, 1996b. 44p. (EMBRAPA-CNPSo. Circular Técnica, 15).

EMPRESA BRASILEIRA DE PESQUISA AGROPECUÁRIA. Centro Nacional de Pesquisa da Soja. Recomendações técnicas para a cultura da soja na regiäo central do Brasil 1997/98. Londrina, 1997. 171p. (EMBRAPACNPSo. Documentos, 106).

FAO. El cultivo de la soja en los trópicos: mejoramiento y producion. Roma, 1995. $254 \mathrm{p}$.

FEHR, W.R.; CAVINESS, C.E. Stages of soybean development. Ames: lowa State University of Science and Technology, 1977. 11p. 
GARCIA, A. Estudo do índice de colheita e de outras características agronômicas de dez cultivares de soja (Glycine max (L.) Merrill) e de suas correlações com a produção de grãos, em duas épocas de semeadura. Viçosa, 1979. 76 p. Dissertação de Mestrado - Universidade Federal de Viçosa.

GAUDÊNCIO, C.; GAZZIERO, D.L.P.; JASTER, F.; GARCIA, A.; WOBETO, C. População de plantas de soja no sistema de semeadura direta para o centro-sul do Estado do Paraná. Comunicado Técnico do Centro Nacional de Pesquisa de Soja, n.47, p.1-4, set. 1990.

MARCOS FILHO, J. Produção de sementes de soja. Campinas: Fundação Cargill, 1986. 86p.

MARCOS FILHO, J.; NOVEMBRE, A D. L. C. C., Características agronómicas e fenologia da soja (Glycine max (L.) Merrill) sob influência da época de semeadura: relatório técnico apresentado ao Conselho de Desenvolvimento Científico (CNPq). Piracicaba, 1990. 57 p.

MEDINA, P.F. Produção de sementes de cultivares precoces de soja, em diferentes épocas e locais do estado de São Paulo. Piracicaba, 1994. 173p. Tese (Doutorado) - Escola Superior de Agricultura Luiz de Queiroz, Universidade de São Paulo.

MIRANDA, M. A C. de.; MASCARENHAS, H. A. Soja: instruções agrícolas para o estado de São Paulo. Campinas: IAC. 1986. p. 193.

NAKAGAWA, J.; MACHADO, J. R.; ROSOLEM, C. A.; MACHADO, J. R. Efeito da densidade de plantas e da época de semeadura na produção e qualidade de sementes de soja. Revista Brasileira de Sementes, n.3, p. 99-112, 1986. 
NAKAGAWA, J.; MACHADO, J. R.; ROSOLEM, C. A. Efeito da densidade de plantas no comportamento de cultivares de soja. Científica, v. 15, n. 1/2, p. 23-36, 1987.

NAKAGAWA, J.; ROSOLEM, C. A.; MACHADO, J. R. Épocas de semeadura de soja. 1. Efeitos na produção de grãos e nos componentes da produção. Pesquisa Agropecuária Brasileira, v.18, n.11, p.1187-1198, 1983.

NAKAGAWA, J.; ROSOLEM, C.A.; MACHADO, J. R. Efeito da densidade de plantas no comportamento de cultivares de soja, em duas épocas de semeadura. Pesquisa Agropecuária Brasileira, v.23, n.9, p.1003-1014, 1988.

ROCHA, V.S.; OLIVEIRA, A. B.; SEDIYMA, T.; GOMES, J. L. L.; SEDIYMA, T. GOMES, J. L. L.; SEDIYMA, C.S.; PEREIRA, M. G. A qualidade da semente de soja. Viçosa: Universidade Federal de Viçosa, 1984. 76p. (Boletim, 188).

ROSOLEM, C. A.; SILVÉRIO, J. C. O.; NAKAGAWA, J. Densidade de plantas na cultura da soja. Pesquisa agropecuária brasileira. v.18, n. 9, p. 977 984, 1983.

SANCHES, A. L.; YUYAMA, K. Época de plantio na cultura da soja (Glycine $\max$ (L.) Merrill), cultivares "Santa Rosa" e "Viçoja" em Jaboticabal, SP. Cientifica, v.7, n.2, p.225-234, 1979.

SEDIYAMA, C.S.; VIEIRA, C.; SEDIYAMA, T.; CARDOSO, A.A.; ESTEVÃO, H. $H$. Influência do retardamento da colheita sobre a deiscência das vagens e sobre a qualidade e poder germinativo das sementes de soja. Experientiae, v.14, n.5, p.117-141, 1972. 
TRAGNAGO, J. L.; BONETTI, L. P. Diferentes épocas de semeadura no rendimento e outras características de alguns cultivares de soja no Rio Grande do Sul. In: SEMINÁRIO NACIONAL DE PESQUISA DE SOJA, 3., Campinas, 1984. Anais. Londrina: EMBRAPA, CNPSo, 1984. p.57-69.

URBEN FILHO, G.; SOUZA, P. I. de M. Manejo da cultura da soja sob cerrado. In: ARANTES, N. E.; SOUZA, P. I. de M. Cultura da soja nos cerrados. Piracicaba: POTAFOS, 1993. p.267-298.

VERnETTI, F. de J. (Coord.). Soja. Campinas: Fundação Cargill, 1983. v.1, p.97-124. 